Cappuyns V., Van Campen A., Helser J. (2021).

Antimony leaching from soils and mine waste from the Mau Due antimony mine, North-Vietnam, Journal of Geochemical Exploration 220, 106663

https://doi.org/10.1016/j.gexplo.2020.106663 


\title{
Antimony leaching from soils and mine waste from the Mau Due antimony mine, North-Vietnam
}

\author{
Valérie Cappuyns ${ }^{1,2, *}$, Axelle Van Campen², Jillian Helser ${ }^{1,2}$ \\ ${ }^{1}$ Center for Economics and Corporate Sustainability (CEDON), KU Leuven, 1000 Brussels, Belgium \\ ${ }^{2}$ Department of Earth and Environmental Sciences, KU Leuven, 3001 Leuven, Belgium \\ *Corresponding author. Tel: +32 2608 1453, E-mail: valerie.cappuyns@kuleuven.be
}

\section{Abstract}

Antimony $(\mathrm{Sb})$ is an element with a growing concern due to its toxicity, but also because of its criticality. While the impact of Sb mining is documented in literature from China and Europe, still little data is available concerning the environmental impact of Sb mining in Vietnam. This paper presents the results of an exploratory study of mine waste and soil samples from the Mau Due mine (North Vietnam). The chemical and mineralogical composition of the samples was determined as well as the water-soluble and exchangeable/reversibly adsorbed Sb species, and the release of Sb at different $\mathrm{pH}$ values was investigated. Antimony concentrations in the mine waste samples (slags and waste rock) were in the range of $186-27221 \mathrm{mg} / \mathrm{kg}$, while soils were characterized by Sb concentrations in the range of $47-95 \mathrm{mg} / \mathrm{kg}$. In one mine waste sample, the primary mineral stibnite was found. The investigated mine waste samples also contained pyrite, which was not found in the soil samples. The leaching of $\mathrm{Sb}$ from all the samples with water was relatively low, as less than $1 \%$ of the total $\mathrm{Sb}$ content in the samples was released. In absolute values, this resulted in water-extractable $\mathrm{Sb}$ concentrations ( $24 \mathrm{~h}$ extraction) up to $430 \mu \mathrm{g} / \mathrm{l}$, except for an alkaline slag sample, which released $23.5 \mathrm{mg} / \mathrm{l}$ of Sb , and the mine waste samples containing stibnite ( $2.9 \mathrm{wt} . \%)$, which released $16.6 \mathrm{mg} / \mathrm{l}$ of $\mathrm{Sb}$. Based on the outcomes of this reconnaissance study, recommendations for further investigation of the waste heaps around the mine were made, taking into account the protection of health and the environment, and the sustainable management of secondary (waste) resources.

Keywords: antimony; leaching; soil; mining waste

\section{Introduction}

Antimony $(\mathrm{Sb})$ is an element with a growing concern due to its toxicity, but also because of its criticality. Antimony was identified as one of 27 critical raw materials for the European Union (European Commission, 2017). Antimony is the $9^{\text {th }}$ most commonly mined element, and has several industrial applications, such as in flame retardants, batteries, weapons, etc. (Alloway, 2013). China is by far the most important producer of Sb in the World (with an Sb production amounting to approximately 100000 metric tons in 2019), followed by Russia and Tajikistan (Statista, 2019). The world's annual production is around 163 ktons of Sb, mostly in China, while it is no longer mined in EU countries (Deloitte sustainability, 2015). Antimony ores are generally processed into Sb metal by mining companies, mainly outside of the EU. Around 50 tons of $\mathrm{Sb}$ is processed in the EU from $\mathrm{Sb}$ ores and concentrates that are imported and about 11000 tons of Sb metal is recovered from secondary material (waste, scrap and ash residues containing Sb) (Deloitte Sustainability, 2015). 
Antimony toxicity mainly occurs due to occupational exposure and may cause respiratory irritation, pneumoconiosis, Sb spots on the skin and gastrointestinal symptoms (Sundar and Chakrvarty, 2010). According to the International Agency for Research on Cancer, antimony trioxide can be carcinogenic to humans (group 2B) and antimony trisulfide is not classifiable as to its carcinogenicity (group 3) (ATSDR, 2017).

Antimony is a metalloid with atomic number 51 , with a high affinity for heavy metals (e.g. $\mathrm{Fe}, \mathrm{Cu}$, $\mathrm{Pb})$, and sulfur. Average Sb concentrations in rocks and soils are in the range of $0.15-2 \mathrm{mg} / \mathrm{kg}$ and 0.3-8.6 mg/kg, respectively (Pierart et al. 2015). In mine waste, and in soils in the vicinity of mines, much higher Sb concentrations are usually found (Okkenhaug et al., 2011). More than a hundred Sbminerals occur on Earth (Anderson, 2012). Antimony is found as a major element in many primary minerals, stibnite being the most common Sb-sulfide (Roper et al., 2012). Dissolution of stibnite $\left(\mathrm{Sb}_{2} \mathrm{~S}_{3}\right)$ in oxidizing conditions releases $\mathrm{Sb}$, and $\mathrm{Sb}$ is incorporated into the mineral structures of several secondary minerals. The most commonly formed secondary $\mathrm{Sb}(\mathrm{V})$ minerals are $\mathrm{Sb}$-bearing Fe hydroxides (goethite $(\alpha-\mathrm{FeOOH})$ and lepidocrocite $(\gamma$-FeOOH$)$ ), together with Sb-bearing jarosite $\left(\mathrm{KFe}_{3}\left(\mathrm{SO}_{4}\right)_{2}(\mathrm{OH})_{6}\right)$ and $\mathrm{Sb}(-\mathrm{Fe})$ oxides and hydroxides such as tripuhyite $\left(\mathrm{FeSbO}_{4}\right)$, senarmontite $\left(\mathrm{Sb}_{2} \mathrm{O}_{3}\right)$, romeite $\left(\mathrm{Ca}_{2} \mathrm{Sb}_{2} \mathrm{O}_{6} \mathrm{OH}\right)$, cervantite $\left(\mathrm{Sb}_{2} \mathrm{O}_{4}\right)$, kermesite $\left(\mathrm{Sb}_{2} \mathrm{~S}_{2} \mathrm{O}\right)$, and valentinite $\left(\mathrm{Sb}_{2} \mathrm{O}_{3}\right)$ (Courtin-Nomade et al., 2012). Antimony is also a component of coal and petroleum (Alloway, 2013). The primary mineral, stibnite, mainly occurs in mineralizations and quartz $\left(\mathrm{SiO}_{2}\right)$ veins. Metalliferous ore mining and smelting industries are currently the main sources of Sb pollution (He et al., 2019).

Antimony occurs in the environment in four oxidation states (-III, 0, III, and V) with $\mathrm{Sb}(\mathrm{III})$ and $\mathrm{Sb}(\mathrm{V})$ being the most frequently occurring species. The oxidation state also determines the toxicity of $\mathrm{Sb}$, which decreases in the following order: $\mathrm{Sb}(\mathrm{III})>\mathrm{Sb}(\mathrm{V})>$ organoantimonials. Microbial transformations catalyze the conversion of one Sb species into another (Mitsunobu et al., 2006; Lehr et al., 2007). At natural pH values, $\mathrm{Sb}$ is present as soluble $\mathrm{Sb}(\mathrm{OH})_{6}{ }^{-}$in oxic systems and as soluble $\mathrm{Sb}(\mathrm{OH})_{3}$ in anoxic ones at natural $\mathrm{pH}$ values. Under reducing conditions, and in the presence of sulfur, stibnite, $\mathrm{Sb}_{2} \mathrm{~S}_{3}(\mathrm{~s})$, is formed at low to intermediate $\mathrm{pH}$ values. At higher $\mathrm{pH}$ values, the $\mathrm{SbS}_{2}{ }^{-}$ species replaces stibnite (Filella et al., 2002a). In soils, $\mathrm{Sb}(\mathrm{OH})_{6}{ }^{-}$represents the major species over a wide Eh range (Mitsunobu et al., 2006).

$\mathrm{pH}$ and microorganisms are key parameters in biogeochemical cycling of $\mathrm{Sb}$ through the dissolution and oxidation of Sb-sulfide and the formation of secondary Sb(V)-bearing minerals (Loni et al. 2020).

$\mathrm{Fe}(\mathrm{hydr})$ oxides play an important role in the sorption and incorporation of $\mathrm{Sb}(\mathrm{V})$ and $\mathrm{Sb}$ (III). Johnston et al. (2020) found a strong association between Sb and poorly-crystalline Fe(III) mineral phases such as ferrihydrite $\left.\left(\mathrm{Fe}_{2} \mathrm{O}_{3}\right) \bullet 0.5 \mathrm{H}_{2} \mathrm{O}\right)$. They also found evidence that $\mathrm{As}(\mathrm{V})$ was more strongly retained in the solid phase than $\mathrm{Sb}(\mathrm{V})$ in an oxic river system. $\mathrm{Sb}(\mathrm{V})$ adsorbs strongly to the surface of goethite and is also readily incorporated into the goethite structure during recrystallization (Burton et al., 2020). At very high aqueous Sb concentrations and near-neutral pH conditions, tripuhyite, is formed, a highly stable $\mathrm{Fe}(\mathrm{III})-\mathrm{Sb}(\mathrm{V})$ oxide (Burton et al., 2020). Adsorption of $\mathrm{Sb}$ (III) to the surface of goethite is rapidly followed by electron transfer from surface-complexed $\mathrm{Sb}$ (III) to structural Fe(III), resulting in the formation of $\mathrm{Sb}(\mathrm{V})$ and Fe(II), forming tripuhyite (Belzile et al., 2001; Leuz et al., 2006). Pyrite can also contain a wide range of trace elements, which includes Sb (Li et al. 2018). Sorption of $\mathrm{Sb}(\mathrm{III})$ and $\mathrm{Sb}(\mathrm{V})$ to $\mathrm{Fe}$ (hydr)oxides and kaolinite is greatly influenced by $\mathrm{pH}$, with increased sorption as $\mathrm{pH}$ decreases, and desorption as $\mathrm{pH}$ increases towards alkaline conditions (Guo et al., 2014a; Rakshit et al., 2015). 
The effect of soil organic matter (SOM) on the mobility of $\mathrm{Sb}$ is somewhat ambiguous. On the one hand, SOM is reported to decrease Sb availability to plants by making stable complexes of Sb-humic acid (Steely et al., 2007). On the other hand, several authors (Clemente et al., 2010; Nakamaru and Peinado, 2017) showed that the application of compost to contaminated soil increased Sb in soil pore water, while Sb uptake by plants did not systematically increase. In waterlogged soils, Verbeeck et al. (2020a) found a decrease in Sb mobility at high Sb concentrations and an increase in Sb mobility at low $\mathrm{Sb}$ concentrations, which was largely determined by the electron donor capacity of SOM. In oxidizing conditions, $\mathrm{Sb}(\mathrm{OH})_{6}$ mobility also increased with increasing $\mathrm{SOM}$ at low soil $\mathrm{Sb}$ concentration, which was explained by competitive sorption on Fe and Al hydroxides (Verbeeck et al. 2019).

While the occurrence of $\mathrm{Sb}$ in the environment is well documented in literature from China (e.g. He, 2007), Europe (e.g. Álvarez-Ayuso et al., 2012; Courtin-Nomade et al., 2012; MacGregor et al., 2015), and Australia (e.g. Johnston et al., 2020; Radková et al., 2020), little data are available concerning the environmental impact of Sb mining in Vietnam (Isuhara and Xian, 2013). This paper presents the first published geochemical leaching characterization data of mine waste, soil and slag samples from the Mau Due mine, in North Vietnam. Mining activities in Vietnam are important for the development of the country. However, mining also causes a loss of natural resources and has a serious impact on the environment (Vu et al., 2012).

This research is an exploratory study of mine waste from the Mau Due mine, and slag and soil samples from the Sb refinery, and is not intended to map the Sb contamination in the area. Besides providing data concerning the chemical and mineralogical composition of mine waste and soils at the Mau Due mine, the release of $\mathrm{Sb}$ is also investigated, under different conditions. Based on the results, a first estimate of the potential risks related to the mining activities and waste disposal is made, with the aim to provide recommendations for further investigation and characterization of the mining waste and slag heaps, in view of more sustainably managing the mining site. Although we were most interested in the release of $\mathrm{Sb}$ from the soil and mine waste samples, we also determined the total elemental concentrations, in order to have a reference for comparison with other studies and with guideline values.

\section{Materials and methods}

\subsection{Site description}

The Mau Due mine is located in the province of Ha Gian, at a latitude of $23^{\circ} 4^{\prime} 44^{\prime \prime}$ North \& longitude $105^{\circ} 14^{\prime} 52^{\prime \prime}$ East in a mountain region in northern Vietnam (Figure 1), close to the Chinese border and to the In-bearing Sn-Pb-Zn deposits of Du Long mine, China (Ishihara et al., 2011). The Songhien formation is the most important host rock of the Mau Due Sb ore body. It is composed of sandstones, black shale and sericitic shale and has a thickness of about $300 \mathrm{~m}$ (Xuan, 2011). The Mau Due Sb deposit is a small fracture filling-type Sb deposit (Ishihara and Xuan, 2013). Three ore bodies extend discontinuously in the North East - South West direction. The main ore body is located in the central part of the area and has a total length of $1300 \mathrm{~m}$ (North East - South West direction). These orebodies are mostly composed of quartz (20-70 \%) and small amounts of calcite $\left(\mathrm{CaCO}_{3}\right)$. The ore minerals are stibnite, and very small amounts of pyrite $\left(\mathrm{FeS}_{2}\right)$, arsenopyrite 
(FeAsS), sphalerite ((Zn, Fe)S), and berthierite $\left(\mathrm{FeSb}_{2} \mathrm{~S}_{4}\right)$ (Ishihara and Xuan, 2013). The average Sb content in the ore ranges from 3.13 to $12.03 \%$ (Xuan, 2011).

Besides the primary ore mineral stibnite, secondary Sb-containing minerals are found, which were formed by the weathering of stibnite $\left(\mathrm{Sb}_{2} \mathrm{~S}_{3}\right)$ : valentinite and lewisite $\left(\mathrm{CaSb}_{2} \mathrm{O}_{5}(\mathrm{OH})_{2}\right)$ (Ishihara and Xuan, 2013).

In 1993, exploitation of the ore body was initiated by open-pit mining. A refinery was installed in 2002. Since 2002, the annual Sb production of the mine amounts to 100 tons (Ishihara and Xuan, 2013), which is a substantial part of the total Sb production in Vietnam, which reached approximately 576 tons in 2017 (Doan, 2020).

The climate in this region is subtropical, with cool winters. The coolest month is January with an average temperature of $15^{\circ} \mathrm{C}$, and the average temperature in August is $29^{\circ} \mathrm{C}$. The average annual precipitation in Ha Gian province is $2492 \mathrm{~mm}$ (source: climate-data.org)

\subsection{Sampling of slag, mine waste and soils}

Samples were collected in January 2015, using a stainless steel shovel. Eight different samples were taken (Figure 1):

- Five mine waste samples, taken from the waste heaps in the center of the area. In the central part of the mining area (Figure 1), surface samples of the mine waste (samples SH1, $\mathrm{SH} 2, \mathrm{SH} 3, \mathrm{SH} 4$, and $\mathrm{SH} 5$ ) were taken along a transect, $150 \mathrm{~m}$ apart. The samples were taken as composite samples, composed of 5 sub-samples, collected in a star-like pattern (Ganne et al., 2006). Since the aim of the study was not to completely map the mining area, but rather to obtain a preliminary idea of $\mathrm{Sb}$ concentrations in the area, a limited amount of samples were taken. Moreover, access to the mine was restricted because it is still operational.

- One slag sample (SL1) of $\pm 1 \mathrm{~kg}$, sampled from a waste heap next to the ore treatment facility. As this was a preliminary study, we were only allowed to take one sample from the slag heap. This sample is not representative of the slag heap. However, for follow-up studies, a more detailed sampling will be performed, but the present study gives an example of characterization methods that can be applied.

- Two soil samples (SO1 and SO2), collected in the vicinity of the slag heap. Soil samples were also taken as a composite sample. Again, this will not allow for mapping of the $\mathrm{Sb}$ contamination in the area, but gives a preliminary indication of $\mathrm{Sb}$ concentrations in soils close to the slag heap. The geochemistry of soil and stream sediments around the Mau Due stibnite deposit has already been investigated (Ishuara and Xuan, 2013), but not the soils nearby the Sb refinery.

\section{Figure 1 here}

The samples were air-dried, and sent to KU Leuven (Belgium) for analysis. Soil and mine waste samples, which all consisted of fine-grained material, were disaggregated in a porcelain mortar. The slag sample was first crushed with a hammer, and then further ground with mortar and pestle. 
Two different dissolution methods were applied to the eight samples: hot plate digestion in which 4 strong acids were used to dissolve the sample, and a fusion method with lithium borate $\left(\mathrm{LiBO}_{2}\right)$. Each sample was digested in duplicate (by both methods), and two blanks and a certified reference material (GBW-7411) (Supplementary material, Table S1) were also included.

\subsubsection{Multi acid digestion method}

The total element concentrations in the samples were determined with a multi-acid digestion procedure using 4 acids $\left(\mathrm{HNO}_{3}\right.$ (nitric acid), $\mathrm{HClO}_{4}$ (perchloric acid), $\mathrm{HF}$ (hydrofluoric acid) and $\mathrm{HCl}$ (hydrochloric acid). Fifty mg of sample was put in a Teflon beaker, together with $1.5 \mathrm{ml}$ of concentrated $\mathrm{HNO}_{3}$, covered and left under the fume hood for 2 days. After 2 days, the Teflon beakers were placed on a hot plate and heated at $140^{\circ} \mathrm{C}$. Subsequently, the beakers were uncovered, and the temperature was increased to $200^{\circ} \mathrm{C}$ to evaporate the $\mathrm{HNO}_{3}$. When the mixture was almost dry, $1 \mathrm{ml}$ of concentrated $\mathrm{HClO}_{4}$ was added to the beaker (covered with a loose cap) and heated at $200^{\circ} \mathrm{C}$ until almost dry. Next, $20 \mathrm{ml}$ of concentrated $\mathrm{HF}$ were added to the beaker and heated at $240^{\circ} \mathrm{C}$ until completely dry. Finally, the residue in the beaker was dissolved by adding 20 $\mathrm{ml}$ of $2.5 \mathrm{~mol} / \mathrm{l} \mathrm{HCl}$ and put on a hot plate until the solid particles were entirely dissolved in the acid solution. The solution was filtered by a Whatman filter and diluted to $50 \mathrm{ml}$ with Milli-Q water.

\subsubsection{Lithium borate fusion}

Fusion is a method where an oxidized sample is dissolved in a molten flux at temperatures of around $1050^{\circ} \mathrm{C}$. Lithium metaborate $\left(\mathrm{LiBO}_{2}\right)$ is mixed with the sample and heated until the lithium borate melts and dissolves the sample to form a homogenous mass. The resulting solid is dissolved in acid for analysis. One hundred $\mathrm{mg}$ of sample was added to $500 \mathrm{mg}$ of $\mathrm{LiBO}_{2}$, in a graphite crucible and heated for $10 \mathrm{~min}$ at $1000^{\circ} \mathrm{C}$ in a muffle furnace, which resulted in the generation of a melt phase $\left(\mathrm{LiBO}_{2}\right.$ pearl). This $\mathrm{LiBO}_{2}$ pearl was poured into $50 \mathrm{ml}$ of $\mathrm{HNO}_{3}(0.42 \mathrm{~mol} / \mathrm{l})$ and stirred on a magnetic stirrer to dissolve the $\mathrm{LiBO}_{2}$ pearl. After $10 \mathrm{~min}$, the pearl was dissolved and the solution was poured into a $50-\mathrm{ml}$ plastic bottle. All measurements were made against calibration curves of five known reference materials which underwent lithium metaborate fusion sample preparation. The solutions of both methods were analyzed for major and trace elements by ICP-OES (Varian-720 ES). Before measurement, the solutions were diluted by a factor 10 with Milli-Q water (see Section 2.5).

\subsection{Mineralogical sample characterization}

All samples were analyzed with XRD (X-ray diffraction). For the XRD identification, a subsample was wet ground ( $5 \mathrm{~min}$ ) by a miller (McCrone Micronizing) using $5 \mathrm{ml}$ of ethanol as a grinding agent. For quantification, an internal standard was added (i.e., $0.2 \mathrm{~g}$ of zincite was combined with $1.8 \mathrm{~g}$ of sample). After being ground, the sample was recuperated in porcelain cups and dried for 1- 2 days under a fume hood. Then, dried samples were gently disaggregated in an agate mortar and passed through a $250 \mu \mathrm{m}$ sieve. Sample holders were gently tapped while filling, to ensure good packing of the grains. A Philips PW1830 diffractometer with Bragg/Brentano $\theta-2 \theta$ setup, CuKa radiation, $45 \mathrm{kV}$ 
and $30 \mathrm{~mA}$, graphite monochromator was used. Mineral phases were identified with the Profex 4.0 software, using the Rietveld refinement method for quantification (Bergmann et al., 1998).

\subsection{Leaching tests}

Leaching tests were performed on all samples with different extraction solutions. The first two extractions were based on the work of Ettler et al. (2007), who used an extraction with demineralized $\mathrm{H}_{2} \mathrm{O}$ (DW) and with $\mathrm{Na}_{2} \mathrm{HPO}_{4} \cdot 2 \mathrm{H}_{2} \mathrm{O} 0.1 \mathrm{~mol} / \mathrm{l}$ to quickly investigate the water-soluble and exchangeable/ reversibly adsorbed $\mathrm{Sb}$ fraction. The influence of alkaline $\mathrm{pH}$ on the mobility of $\mathrm{Sb}$ was assessed further by means of extractions with diluted Na solutions, with concentrations varying between $0.005 \mathrm{~mol} / \mathrm{l}$ and $0.1 \mathrm{~mol} / \mathrm{l} \mathrm{NaOH}$.

Additionally, the EN 12457-2 test was performed according to the guidelines of the European Committee for Standardization (CEN). It specifies a compliance test providing information on leaching of granular wastes and sludges under the experimental conditions and is used to classify waste materials in the EU (EN 12457-2, 2002).

$1 \mathrm{~g}$ of each sample was weighed in a polyethylene centrifuge tube. In each tube, $10 \mathrm{ml}$ of extraction fluid was added, and the tubes were fixed on a horizontal shaking device (Edmund Buhler Gmbh) and shaken for 2 or $24 \mathrm{~h}$ (see Table 1 for the operational parameters). After centrifugation (15 min., 3000 rpm, Beckman G6 centrifuge), the solution was separated from the solid sample, and the $\mathrm{pH}$ of each solution was measured with a Hamilton Single Pore Glass pH-electrode. Before ICP-OES analysis, the solutions were filtered $(0.45 \mu \mathrm{m})$.

\section{Table 1 here}

\subsection{Analyses of digests and leachates}

Elemental concentrations ( $\mathrm{Al}, \mathrm{Ca}, \mathrm{Fe}, \mathrm{K}, \mathrm{Mg}, \mathrm{P}, \mathrm{S}, \mathrm{Sb}, \mathrm{As}, \mathrm{Cd}, \mathrm{Co}, \mathrm{Cr}, \mathrm{Cu}, \mathrm{Mn}, \mathrm{Mo}, \mathrm{Ni}, \mathrm{Pb}$ and $\mathrm{Zn}$ ) in the digests and the leachates were measured by ICP-OES (Varian 720ES).

Calibration solutions were prepared from certified multi-element ICP standard stock solutions and from Plasma HIQU single element solutions from CHEM-LAB (Belgium). Blanks were also included in the calibration. All solutions were prepared from $18 \mathrm{M} \Omega / \mathrm{cm}^{3}$ ultra-pure water supplied from a millipore system and stabilized with ultra-pure nitric acid (CHEM-LAB). Each measurement was carried out with three replicates. Speciation-equilibrium calculations were performed with the computer program PHREEQC (Parkhurst and Appelo, 1999), with the database minteq.v4.dat (Gustafsson, 2013), and using specific reactions for Sb phases from Majzlan et al. (2016).

\section{Results}

\subsection{Total element concentrations and mineralogy}

Very high Sb concentrations, up to $15700 \mathrm{mg} / \mathrm{kg}$ were measured in the slag sample, as well as in some mine waste samples (Table 2). Mine waste samples $\mathrm{SH} 3, \mathrm{SH} 4$, and $\mathrm{SH} 5$, show moderate Sb- 
concentrations. Both soil samples ( $\mathrm{SO} 1$ and $\mathrm{SO} 2$ ) are clearly contaminated with $\mathrm{Sb}$, but concentrations are much lower than in the slag and mine waste. Heavy metals such as $\mathrm{Cr}, \mathrm{Cu}, \mathrm{Pb}$, and $\mathrm{Zn}$ did not display particularly high concentrations (Table 2 ). In the discussion section, most attention will go to $\mathrm{Sb}$, as this is the main metal(loid) in the samples. Occasionally, results for As will also be briefly discussed.

\section{Table 2 here}

Quartz (23-46 wt.\%), clay minerals (2.4-7.8 \% wt.\%), micas (20-49\% wt.\%) and gypsum (0.8-8.1\% wt.\%) were the main minerals in all mine waste samples (SH1 to $\mathrm{SH} 5$ ), except in sample $\mathrm{SH} 1$ and $\mathrm{SH} 2$, where respectively $26 \%$ and $21 \%$ of dolomite $\left(\mathrm{CaMg}\left(\mathrm{CO}_{3}\right)_{2}\right)$ was also present. These were also the only samples containing calcite $\left(\mathrm{CaCO}_{3}\right.$, resp. 0.7 and $2.5 \mathrm{wt}$.\%). Stibnite was the only Sb-bearing mineral found in one of the mine waste samples (sample SH2). The mine waste samples also had $0.9-3.9 \%$ of pyrite.

In the slag sample (SL1), quartz was the main mineral, next to cristobalite (polymorph of quartz), calcite $\left(\mathrm{CaCO}_{3}\right)$, and augite $\left((\mathrm{Ca}, \mathrm{Na})(\mathrm{Mg}, \mathrm{Fe}, \mathrm{Al}, \mathrm{Ti})(\mathrm{Si}, \mathrm{Al})_{2} \mathrm{O}_{6}\right)$. A Sb bearing minerals, namely cervantite (0.7 wt.\%) was also detected.

Quartz, clay minerals (illite and kaolinite), and micas were the main minerals found in the soil samples, with small amounts of feldspars, augite and goethite (Supplementary material, Table S2).

\subsection{Leaching tests}

The extractions with water and with the $0.1 \mathrm{~mol} / / \mathrm{Na}_{2} \mathrm{HPO}_{4} \cdot 2 \mathrm{H}_{2} \mathrm{O}$ solution, showed high variability with respect to the leaching of elements, and the pH of the extracts (Figure 3). From 0.06 to $1.7 \%$ of the total Sb content of the samples was extracted with water ('water-soluble Sb'), and 0.1 to $2.5 \%$ with the phosphate solution ('reversibly/exchangeable Sb'). The diluted 0.005, 0.01 and $0.1 \mathrm{~mol} / \mathrm{l}$ $\mathrm{NaOH}$ solutions extracted more $\mathrm{Sb}$ as the $\mathrm{OH}$ - concentrations increased, which was expected based on the occurrence of $\mathrm{Sb}$ as anionic species. The $\mathrm{pH}$ of the $0.005 \mathrm{~mol} / \mathrm{l} \mathrm{NaOH}$ extract was in the range 2.6-10.9 after extraction, pointing to a different base neutralization capacity of the different samples. With the $0.01 \mathrm{~mol} / \mathrm{I} \mathrm{NaOH}$ solution, the $\mathrm{pH}$ after extraction was in the range 7.1- 11.8. The $\mathrm{pH}$ of the extract after extraction with $0.1 \mathrm{~mol} / \mathrm{I} \mathrm{NaOH}$ was comparable for all samples, namely 12.9 \pm 0.1 .

\section{Figure 2 here}

\section{Discussion}

\subsection{Comparison between sample digestion techniques}

In general, the determination of Sb in solid samples such as waste, soils and sediments received less attention than the determination of $\mathrm{Sb}$ in water samples, where the speciation of $\mathrm{Sb}$ has also been a frequently addressed research topic (e.g. Kumar and Riyazuddin, 2007; Hasanin et al., 2016). Many 
different methods have been used for the determination of total or pseudo-total concentrations of $\mathrm{Sb}$ in soils, sediments, and waste materials. An overview of studies dealing with the determination of $\mathrm{Sb}$ in (mining) waste samples is provided in Table 3. With respect to destructive methods, acid digestion methods are most often used, using different combinations of acids and either a hot plate or a microwave to digest the samples (Table 3). Pseudo-total Sb concentrations are often determined by aqua regia destruction, but sometimes other, more aggressive, acid digestion techniques are used.

The recovery of $\mathrm{Sb}$ concentrations from environmental samples depends on the extraction method chosen (Hjortenkrans et al., 2009). Therefore, the choice of reagents for sample digestion requires careful consideration to ensure adequate matrix dissolution and prevent the formation of insoluble Sb-bearing precipitates (Nash et al., 2000). Most acid dissolution methods do not completely dissolve the solid samples and provide 'pseudo-total', or 'near-total' concentrations of Sb. Tighe et al. (2004) compared open hot plate digestion and microwave digestion methods with nitric acid or aqua regia to determine near-total $\mathrm{Sb}$ concentrations in a contaminated floodplain and found that the aqua regia microwave destruction method performed better in terms of reproducibility than a nitric acid digestion method (microwave and hot plate).

Only a few studies using non-destructive techniques were found in published literature. Instrumental Neutron Activation Analysis (INAA) (Murciego et al., 2007) and X-ray fluorescence (XRF) (Marriussen, 2012) were used to measure Sb concentrations, respectively floodplain soils and in soils from a firing range. XRF is less suitable for Sb analysis, especially in organic-rich soil, but may be used on powdered mineral soil if the concentration is higher than $50 \mathrm{mg} / \mathrm{kg}$ (Mariussen 2012).

In the present study, two digestion methods, namely a hot plate multi-acid digestion and a lithium metaborate fusion were performed, and the performance of both destruction techniques were compared (Figure 3). Fusion involves the complete dissolution of the sample in a melt (molten) flux. Fusions are generally more aggressive than acid dissolution methods. A disadvantage is that there can be a loss of volatile elements (e.g., $\mathrm{As}, \mathrm{Pb}, \mathrm{Sb}$ ) during this type of digestion. The multi-acid digestion uses a combination of 4 concentrated acids: $\mathrm{HNO}_{3}, \mathrm{HClO}_{4}, \mathrm{HF}$ and $\mathrm{HCl}$. $\mathrm{HCl}$ is known to dissolve silicate, iron and sulfide minerals, especially at elevated temperatures and pressures (Pahlavapour et al., 1980; Kammin and Brandt, 1988). Tighe et al. (2005 a, b) showed that iron oxyhydroxides, silicates, and sulfide phases often play an important role in the binding of Sb. The use of concentrated $\mathrm{HNO}_{3}$ is necessary for the digestion of soil samples to release $\mathrm{Sb}$ from any organic matter. HF dissolves silicate minerals, but some refractory minerals (especially oxide minerals) are only partially digested. Therefore, the multi-acid digestion used in this study can be considered a near-total digestion.

\section{Table 3 here}

The incomplete dissolution of the samples by the multi-acid digestion method can be deduced from the comparison with the $\mathrm{LiBO}_{2}$ fusion method (Figure 3). For most major elements, such as $\mathrm{Fe}, \mathrm{Al}, \mathrm{K}$, $\mathrm{Mg}$, higher concentrations are obtained with the $\mathrm{LiBO}_{2}$ fusion method than with the multi-acid digestion method (Figure 2 for Fe), which is most likely related to the incomplete dissolution of the slag material by the multi-acid digestion. For heavy metals and metalloids, the difference between both digestion methods is less pronounced. Only for the slag sample (SL1), much more Sb was 
measured with the $\mathrm{LiBO}_{2}$ method $(27221 \mathrm{mg} / \mathrm{kg}$ ), than with the multi-acid digestion method (11 522 $\mathrm{mg} / \mathrm{kg}$ ) (Figure 2), pointing to the incorporation of $\mathrm{Sb}$ in phases that are resistant to the multi-acid digestion. Fe-minerals, such as goethite, ferrihydrite, and tripuhyite can act as sinks for Sb (Karimian et al., 2018; Radková et al., 2020), but are most likely dissolved by the acid digestion. Refractory Feminerals in the slag, however, were not dissolved by the multi-acid digestion.

For the soil samples, concentrations of Sb are comparable with both methods. Telford et al. (2008) compared Sb extracted with a multi-acid dissolution method (using the same 4 acids as in the present study). Antimony concentrations extracted from contaminated soils by the 1:2 (v/v) $\mathrm{HNO}_{3}: \mathrm{HCl}$ acid mixture at $150{ }^{\circ} \mathrm{C}$ were similar to $\mathrm{Sb}$ extracted by the four acid mixture. In what follows, we will use the results of the multi-acid digestion for metalloids (including Sb), heavy metals, and $\mathrm{S}$, and the results of the $\mathrm{LiBO}_{2}$ fusion for major elements (Table 2).

\section{Figure 3 here}

\section{2 $\mathrm{Sb}$ in mine waste}

In the present study, both mine waste samples with rather low and with very high Sb concentrations were found. Guo et al. (2014b) found Sb concentrations of 6930 and $11100 \mathrm{mg} / \mathrm{kg}$ in water resp. quenched and desulfurized slags produced in the smelting processes in the Xikuangshan area. Tailings and slag residues from an old Sb mine of the French Massif Central have been reported to have concentrations of $\mathrm{Sb}$ in slags and tailings of 1700 and $5000 \mathrm{mg} / \mathrm{kg}$, respectively (CourtinNomade et al., 2012).

Stibnite in mesothermal vein deposits of eastern Australia and southern New Zealand is oxidized under humid to semiarid conditions and transforms to oxides including valentinite, senarmontite, and stibiconite $\left(\mathrm{Sb}^{3+} \mathrm{Sb}^{5+}{ }_{2} \mathrm{O}_{6}(\mathrm{OH})\right.$. Oxidation of stibnite and associated arsenopyrite and pyrite causes local acidification, which is readily neutralized by carbonates in mineralized zones and host rocks. Stibnite dissolves readily in moderately oxidized waters $\left(\mathrm{SbO}_{3}{ }^{-}\right)$, with the formation of $\mathrm{Sb}$ oxide, and Sb sorption/coprecipitation with amorphous iron oxyhydroxides (Ashley et al., 2003). Secondary Sb minerals are most likely formed in the immediate vicinity of the oxidizing primary mineral (Diemar et al., 2008). At very high aqueous Sb concentrations and near-neutral pH conditions, tripuhyite is formed, a highly stable Fe(III)-Sb(V) oxide (Burton et al., 2020).

Samples SH2 still contains stibnite and pyrite, indicating that it is not (fully) oxidized yet. In the slag sample, cervantite was found, the oxidation product of stibnite that is is often encountered in the stibnite oxidation zone (Ashley et al., 2003).

High variability was observed with respect to the $\mathrm{pH}$ of the mine waste samples. Whereas sample $\mathrm{SH} 1$ and $\mathrm{SH} 2$ displayed a neutral pH, samples $\mathrm{SH} 3$ and $\mathrm{SH} 5$ were moderately acidic, and sample $\mathrm{SH} 4$ even very acidic (Table 3 ). These observations suggest that sample $\mathrm{SH} 4$ is older, and already underwent weathering, producing acid mine drainage, while mine waste with a neutral $\mathrm{pH}$ and slightly acidic $\mathrm{pH}$ still contains some carbonates, which can buffer acidity produced by the oxidation of sulfides. The samples with a neutral $\mathrm{pH}$ ( $\mathrm{SH} 1$ and $\mathrm{SH} 2$ ) indeed contained dolomite and carbonate, whereas these minerals were not found in the other mine waste samples.

No relationship was however found between the S-, and Ca-content of the samples, and the $\mathrm{pH}$. The slag sample in this study (SL1) is Si-rich slag, with a low Fe content, and an alkaline $\mathrm{pH}$. It is 
characterized by a high Sb content (1.15 wt.\%), but low concentrations of As and heavy metals (Table 2).

Antimony is listed among the 27 critical raw materials for the EU (European Commission, 2017). In view of resource protection, the potential for recovery of Sb from the mine waste and slags, considering it as a secondary resource, should be investigated. This asks first of all for a more detailed mapping and characterization of the mine waste and slags at Mau Due, in order to more exactly know where highly concentrated waste materials can be found on the site, and estimate how much of these materials are available. Based on that information, the recovery of Sb from mine waste and slags could be considered. In a review on the recovery of Sb from end-of-life products and industrial process residues, Dupont et al. (2016) pointed out that residues from the processing of metal ores with high contents of Sb are currently discarded or stockpiled, causing environmental concerns. Technologies for Sb recycling are available, but upscaling of these methods is necessary, taking into account economic feasibility as well as environmental issues.

\subsection{Sb in soils}

High concentrations of Sb and other heavy metals and metalloids are usually not limited to the waste materials stored on mining sites themselves. Soils and sediments, as well as ground and surface water in and around the mining and smelting sites also suffer from pollution. Several studies on metallic pollution arising from the mining of Sb-ores, as well as dry fallout/fly ash and solid waste from smelters have been conducted in the proximity of mining and metallurgical sites. Sometimes samples were taken on the mining site itself, or in the broader mining area, including soils in the neighborhood of the site (Table 3). Yuan et al. (2017) found concentrations in the range of 289-3100 $\mathrm{mg} / \mathrm{kg}$ in soils flooded by smelting wastewater from a former stibnite, antimonite $\left(\mathrm{FeSb}_{2} \mathrm{~S}_{4}\right)$ and plagionite $\left(\mathrm{Pb}_{5} \mathrm{Sb}_{8} \mathrm{~S}_{17}\right)$ smelter. In literature (Table 3), mining-impacted soils with Sb concentrations up to $11798 \mathrm{mg} / \mathrm{kg}$ have been reported (Okkenhaug et al., 2011).

In soil samples taken nearby (up to $1 \mathrm{~km}$ from the mine) the Sb mine of the Xikuangshan Sb deposit, in which stibnite $\left(\mathrm{Sb}_{2} \mathrm{~S}_{3}\right)$ is the only ore mineral, has Sb levels ranging from 101 to $5045 \mathrm{mg} / \mathrm{kg}$ (He, 2007). Ishara and Xuan (2013) report that the pollution of soils and sediments due to As and base metals around the Mau Due stibnite deposits was "weak", with an average Sb concentration of 932 $\mathrm{mg} / \mathrm{kg}$ in the soil in the wet season, and $342 \mathrm{mg} / \mathrm{kg}$ of Sb in the dry season. The Sb content of stream sediments are much higher (average of $2536 \mathrm{mg} / \mathrm{kg}$ in the wet season and $2504 \mathrm{mg} / \mathrm{kg}$ in the dry season). The soil samples analyzed in the present study were taken close to the smelter, and display $\mathrm{Sb}$ concentrations which are comparable to the concentrations reported in Ishara and Xuan (2013). Nevertheless, compared to Sb concentrations in soils not affected by mining and smelting activities, which are of the order of a few mg/kg (Filella et al., 2002), these values cannot be considered 'weak', and clearly carry the signature of the stibnite deposit and related mining and smelting activities in the area.

Background values for Sb in soils have only been established in a few countries. In Cuba, the quality reference value, based on the analysis of soils under natural conditions with little or minimal anthropic interference, was established at $6 \mathrm{mg} / \mathrm{kg}$ for Sb (Alfaro et al., 2015). The background values of Sb in Chinese soils are in the range of $0.8-3.0 \mathrm{mg} / \mathrm{kg}$ (Qi and Cao, 1991). In European soils, (median of a dataset of resp. 783 and 840 samples) Sb concentrations are $0.47 \mathrm{mg} / \mathrm{kg}$ in subsoil and $0.60 \mathrm{mg} / \mathrm{kg}$ in topsoil. Enrichments of Sb in the soil are mainly related to ore deposits, and old 
mining and smelting areas, with maximum values of $30.3 \mathrm{mg} / \mathrm{kg}$ in subsoils and $31.1 \mathrm{mg} / \mathrm{kg}$ in topsoils (Salminen et al., 2005). In a reconnaissance soil geochemical survey near Armidale, New South Wales (Australia), anomalous soil Sb levels (up to $150 \mathrm{mg} / \mathrm{kg}$ ) were confined to within $100 \mathrm{~m}$ of known stibnite mineralization (Diemar et al. 2009). Several authors (Wilson et al., 2004; Diemar et al., 2009) state that the mobility of Sb in soils is quite limited such that Sb levels are confined to the immediate vicinity of the oxidizing Sb minerals.

Compared to the mine waste and slag samples, the soil samples (SO1 and SO2), taken in the vicinity of the smelter, were characterized by a lower Si-, Mn-, S- and Fe-content, but higher Mg- and Caconcentrations (Table 2).

Arsenic is often found as a pollutant of Sb mining and smelting. However, we found a low to moderate enrichment of As in the mine waste and the soils, and there was no correlation between total As and Sb concentrations.

\subsection{Water-soluble and reversibly sorbed/exchangeable Sb}

The $0.1 \mathrm{~mol} / \mathrm{I} \mathrm{Na} \mathrm{HPO}_{4}$-extractable Sb concentration is used to estimate the "exchangeable" or "reversibly sorbed" Sb pool (Ettler et al., 2007). The $0.1 \mathrm{~mol} / \mathrm{I} \mathrm{Na} 2 \mathrm{HPO}_{4} . \mathrm{H}_{2} \mathrm{O}$ solution resulted in slightly higher extractability of Sb compared to an extraction with water (Figure 2). However, this difference was not significant ( $p>0.1$ ). The soil samples SO1 and SO2 showed a low release of Sb with water (108 and $21 \mu \mathrm{g} / \mathrm{l}$, respectively) and a slightly higher release with $0.1 \mathrm{~mol} / \mathrm{I} \mathrm{Na} \mathrm{HPO}_{4} .2 \mathrm{H}_{2} \mathrm{O}$ (116 and $26 \mu \mathrm{g} / \mathrm{I}$ respectively), which represents $0.73-1.25 \%$ of the total content in the soil. It cannot be deduced from the results whether this is due to the effect of increasing phosphate concentrations or to the increase in $\mathrm{pH}$. For the samples with a $\mathrm{pH}<7$ (SH3, SH4, SH5, SO1, and SO2), the $\mathrm{pH}$ of the phosphate extract was 2 to 4 units higher than the $\mathrm{pH}$ measured in water. For the samples with a $\mathrm{pH}>7$, this difference was less than $1 \mathrm{pH}$ unit (Figure 2).

Antimony exists as either a neutral species or a negatively charged oxyanion. Phosphate ions can compete with Sb oxyanions bound to the surfaces of Fe(hydr)oxides, clay minerals and organic matter. Griggs et al. (2011) demonstrated the increased leaching of Sb in phosphate-treated soils compared to untreated control soils. Verbeeck et al. (2019), using a $0.1 \mathrm{~mol} / \mathrm{I} \mathrm{Na} \mathrm{HPO}_{4} \cdot \mathrm{H}_{2} \mathrm{O}$ solution, extracted $1-4 \%$ of the total Sb in soil samples containing between 0.7 and $24 \mathrm{mg} / \mathrm{kg} \mathrm{Sb}$, and a varying SOM content. Ettler et al. (2007) also used an extraction with the same phosphate concentration as the present study, and reported a much more pronounced effect of phosphate on the mobilization of $\mathrm{Sb}$, but the $\mathrm{pH}$ of the phosphate extract was also much lower than the $\mathrm{pH}$ obtained for our samples, pointing to a different $\mathrm{pH}$ buffering capacity of the soils. Similarly to our results, Park et al. (2018) reported that phosphate was not effective in the mobilization of an artificially contaminated soil $\left(\mathrm{Sb}_{\text {tot }}=100 \mathrm{mg} / \mathrm{g}\right.$ ). They used a $0.02 \mathrm{~mol} / \mathrm{I}$ phosphate solution, which is five times more diluted than the solution used in the present study. Whereas phosphate decreases $\mathrm{Sb}(\mathrm{V})$ adsorption on goethite, the influence of sulfate is minimal (Essington and Stewart, 2018). In a combined laboratory and field study, Rouwane et al. (2015) found that Sb release was favored under oxidizing conditions, particularly when dissolved organic carbon (DOC) increased in soil pore water (up to $92.8 \mathrm{mg} / \mathrm{l}$ ). At

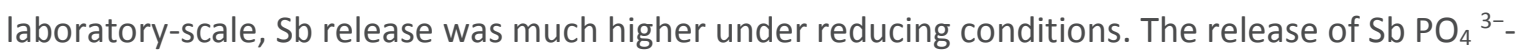
enriched anoxic soils was probably induced by the combined competitive effect of hydrogen carbonates and phosphates for soil binding sites, pointing to the importance of the (alkaline) pH. 
The low 'water-soluble' Sb fraction is in line with what has been reported for other soils impacted by $\mathrm{Sb}$ mining, despite the fact that most published results present data from closed mines.

Murciego et al. (2007) evaluated the water-soluble Sb fraction in mine soils ( $\mathrm{pH} 4.3-7.2)$ following the DIN 38414-S4 (1984) procedure. This method uses deionized water, with a liquid: soil ratio of $1000 \mathrm{ml}: 100 \mathrm{~g}$, and a shaking period of $24 \mathrm{~h}$, and is thus comparable to the EN $12457-2$ test. The water-soluble fraction was in the range of $1-20 \mathrm{mg} / \mathrm{kg}$, accounting for $0.13-7.33 \%$ of the total $\mathrm{Sb}$ content in the soils. The soluble Sb content in Scottish soils, determined with $1 \mathrm{~mol} / \mathrm{I} \mathrm{NH}_{4} \mathrm{NO}_{3}$ was on average $1.2 \%$ (range $0.01-8.8 \%$ ) in soils with an acidic to slightly acidic pH (Gál et al., 2007). The water extracts of topsoils from a polluted Sb smelting site in China contained 5.3-31.6 mg/kg of soluble $\mathrm{Sb}$, which was $0.7-1.63 \%$ of the total $\mathrm{Sb}$ content in the soil (Sh et al., 2012).

To simulate the release of Sb from the soil at Su Suergiu (Italy), Cidu et al. (2014) performed batch tests with MilliQ water ( $\mathrm{L} / \mathrm{S}=25 \mathrm{l} / \mathrm{kg}$ ) using Sb-rich soil samples (4400 and $860 \mathrm{mg} / \mathrm{kg}$ ) with a neutral pH. 1 to $6 \%$ of the total Sb content was released with water after $96 \mathrm{~h}$.

Álvarez-Ayuso et al. (2012) reported soluble Sb ranging from < 0.01-0.779 mg/kg (EN 12457-2 test), which represented $<1 \%$ of the total $\mathrm{Sb}$ content of the soils (with a $\mathrm{pH}$ ranging from $6.6-8.0$ ). All of these examples show that the mobility of Sb in soils, affected by mining, at acidic to slightly alkaline $\mathrm{pH}$ is rather low, with generally less than $10 \%$ of the total $\mathrm{Sb}$ content being released by water extraction. However, in absolute concentrations, sometimes very high Sb concentrations are found in the water extracts (e.g., $2.2 \mathrm{mg} / \mathrm{l}$; Cidu et al., 2014, $12.9 \mathrm{mg} / \mathrm{l}$; Murciego et al., 2007) of these highly contaminated mine soils.

There are no guideline values available for soluble heavy metal and metalloid concentrations in soils. As a reference, we could compare these water-soluble Sb concentrations in soils with values for surface and groundwater, and drinking water. In non-polluted waters, total dissolved Sb concentrations are usually less than $1.0 \mu \mathrm{g} / \mathrm{l}$ (Filella et al., 2002). According to the USEPA (2018), the maximum contaminant level for Sb in water was set at $6 \mu \mathrm{g} / \mathrm{l}$ for lifetime exposure of a $70 \mathrm{~kg}$ adult consuming $2 \mathrm{I}$ of water daily. Guideline values for one-day and ten-days (10-kg child consuming $1 \mathrm{I}$ of water per day) are reported as $10 \mu \mathrm{g} / \mathrm{I}$. In Canada, the maximum acceptable concentration (MAC) for $\mathrm{Sb}$ in drinking water is set at $4 \mu \mathrm{g} / \mathrm{I}$ (Health Canada, 1999). In the European Union, a parametric standard for Sb is included in the EU Drinking Water Directive (EU, 1998), which equals $5 \mu \mathrm{g} / \mathrm{l}$. The World Health Organization (WHO) has provided guidelines for drinking water quality of $20 \mu \mathrm{g} / \mathrm{I}$ (WHO, 2003), but some polyethylene terephthalate-bottled waters often contain higher levels of Sb when stored over an extended-time (2 weeks) in high-temperature $\left(60^{\circ} \mathrm{C}\right)$ storage conditions (Carneado et al., 2015). The Sb content from water extraction of the soil samples (SO1 and SO2) are slightly above $20 \mu \mathrm{g} / \mathrm{l}$. Despite the fact that this exceeds all guidelines for drinking water quality, we can still conclude that the solubility of $\mathrm{Sb}$ in the soils is rather low, which might be partly explained by the acid pH of the soils ( $\mathrm{pH} 5.0$ and 4.8), favoring the sorption of anionic Sb species.

For the mine waste samples, a longer extraction time ( $24 \mathrm{~h}$ vs. $2 \mathrm{~h}$ ) had a significant effect on the solubility of Sb, pointing to the importance of reaction kinetics (Figure 2). The European Union established guideline values, based on the EN 12457-2 leaching test (extraction with water at L/S 10 $\mathrm{l} / \mathrm{kg}, 24 \mathrm{~h}$ ), to classify waste as hazardous or non-hazardous waste. Based on these guidelines, only samples SL1 and SH2 exceed the guideline value for hazardous waste for Sb (Figure 3), while samples $\mathrm{SH} 1$ and $\mathrm{SH} 4$ also exceed the guideline value for non-hazardous waste. 
$\mathrm{Sb}$ mobility is determined by many different parameters, and a comparison between different studies is not always straightforward. An important aspect here is also that the Sb-content of the mine waste is not always proportional to the amount of $\mathrm{Sb}$ released from the samples. Hu et al. (2016) even showed that the extent of Sb dissolution is negatively correlated with the Sbconcentration in the mineral phase. In the present study, the mine waste samples with the highest $\mathrm{Sb}$ content released between 1 and $2 \%$ of their total Sb content, while the samples with a lower total $\mathrm{Sb}$ content released less than $0.5 \%$ of their total Sb content. The negative correlation between total and water-soluble $\mathrm{Sb}$ concentrations was thus not found in the present study.

With respect to other contaminants, water-soluble As-concentrations were in the range of 10-572 $\mu \mathrm{g} / \mathrm{l}$, with sample $\mathrm{SH} 3$ and $\mathrm{SH} 4$ exceeding the guidelines for non-hazardous waste. These two samples, with an acidic to strongly acidic pH (resp. 5.2 and 2.6), also displayed the highest release of $\mathrm{Cd}, \mathrm{Cr}, \mathrm{Cu}, \mathrm{Ni}$ and $\mathrm{Zn}$. However, the EU guidelines for hazardous waste were only exceeded for $\mathrm{Ni}$ and $\mathrm{Cu}$ (Supplementary material, Table S3).

\subsection{Influence of $\mathrm{pH}$ on the release of $\mathrm{Sb}$}

The release of Sb increased towards more alkaline $\mathrm{pH}$ (Figure 4). The most prominent release was observed for the samples with the highest total content of Sb (SH2 and SL1, Table 2). Relative to the pseudo-total Sb concentration, most Sb was released from the mine waste samples (Figure 4, SH2, up to $14 \%$; for the other mine waste samples, between 5 and $52 \%$ of Sb was leached with the 0.1 $\mathrm{mol} / \mathrm{l} \mathrm{NaOH}$ solution), while only $3 \%$ of the total $\mathrm{Sb}$ content was released from the slag sample (SL1) at pH 12 (which equals to $396 \pm 10 \mathrm{mg} / \mathrm{kg}$, Figure 4).

\section{Figure 4 here}

\subsubsection{Sb release from soils}

From the soil samples SO1 and SO2, resp. 17 and $2 \%$ of the total Sb content was released with $\mathrm{NaOH} 0.1 \mathrm{~mol} / \mathrm{l}$. Serafimovska et al. (2013) used $0.1 \mathrm{~mol} / \mathrm{l}$ of $\mathrm{NaOH}$ to isolate the soil fraction containing humic substances from soil samples, and found that between 6.1 and $13.7 \%$ of the total $\mathrm{Sb}$ content was bound to soil humic acids. Using sorption experiments, Buschmann and Sigg (2004) showed that over $30 \%$ of total Sb(III) may be bound to humic acids. Steely et al. (2007) indicated that humic acids have a strong binding capacity for Sb, being able to immobilize it in the soil's organic layer. Besides the dissolution of humic acids at high $\mathrm{pH}$, sorption of $\mathrm{Sb}(\mathrm{V})$ by humic acid also decreases as the $\mathrm{pH}$ increases.

The effect of soil pH on Sb mobility in soil is not always straightforward, and also depends on the redox status of $\mathrm{Sb}$. In the $\mathrm{pH}$ range $2-11, \mathrm{Sb}(\mathrm{III})$ exists as, $\mathrm{Sb}(\mathrm{OH})_{3}$, a neutral complex, and $\mathrm{Sb}(\mathrm{V})$ exist as the negatively charged $\mathrm{Sb}(\mathrm{OH})^{-}$(Filella et al. 2002). $\mathrm{Sb}(\mathrm{OH})_{6}$ is also the main $\mathrm{Sb}$ species over a wide range of Eh values in soil (Wilson et al. 2010).

Tighe et al. (2005b) reported a strong sorption capacity of amorphous Fe-oxides for $\mathrm{Sb}(\mathrm{V})$ in the $\mathrm{pH}$ range from 3-6.5. Humic acids can significantly contribute to the sorption of $\mathrm{Sb}(\mathrm{V})$ at these $\mathrm{pH}$ values. However, increasing soil pH can decrease the Sb holding capacity of humic acids, both for 
$\mathrm{Sb}$ (III) and Sb(V) (Tighe et al., 2005b, Buschmann and Sigg, 2004). According to Casiot et al. (2007), Fe-oxides are considered as the main sorbing phase for $\mathrm{Sb}$, and the mobility of $\mathrm{Sb}(\mathrm{V})$ in oxidizing conditions is higher than $\mathrm{Sb}(\mathrm{III})$ because of the smaller charge density and large ionic radius in the form of $\mathrm{Sb}(\mathrm{OH})_{6}{ }^{-}$. Antimony also strongly adsorbs onto clay minerals and hydrous Al-oxides (Ilgen and Trainor, 2012; Rakshit et al., 2015). It was not the aim of the present study to deduce the binding mechanisms of Sb onto soil components. However, based on the information about Sb occurrence in soil described above, the acidic $\mathrm{pH}$ values of the soil ( $\mathrm{pH} 5.0$ and 4.8) explain the low mobility of $\mathrm{Sb}$. A substantial increase in the $\mathrm{pH}$ of the soils should be avoided, as this will result in the release of Sb. Recently, indications were found that Sb mobility increases upon aging of soils, suggesting that soils affected by historical contamination could have lower Sb mobility and bioavailability of $\mathrm{Sb}$ than recently contaminated soils (Verbeeck et al., 2020b). The Mau Due mine started its operations in 1993, and is still operational, resulting in both historical and new contamination. A better understanding of the factors affecting $\mathrm{Sb}$ mobility upon aging of soils would be useful to develop strategies to prevent $\mathrm{Sb}$ from migrating downwards to groundwater. Arsenic is usually also found in the waste from Sb mining, and in soils contaminated by Sb mining and smelting. In addition, the geochemistry of $\mathrm{Sb}$ is often considered similar to that of As, although more recent studies (e.g. Fu et al., 2016) suggest that significant differences in mobility, bioavailability and bioaccumulation exist between As and Sb. The extraction with $0.01 \mathrm{~mol} / \mathrm{l}$ of $\mathrm{NaOH}$ solution released respectively 5.2 and $22.5 \%$ of the pseudo-total As-content of soils SO1 and SO2. The release as a function of $\mathrm{pH}$ follows the same pattern as $\mathrm{Sb}$ (i.e., increased leaching as $\mathrm{pH}$ increases, Figure S1, Supplementary material), but proportionally less As is released from sample $\mathrm{SO1}$. The natural co-occurrence of As with $\mathrm{Sb}$, which are often believed to behave similarly, but which is definitely not always the case, offer an interesting further research opportunity for the soils and waste materials at the Mau Due mine.

\subsubsection{Sb release from mine waste and slag}

With respect to the mine waste and slag samples, the solubility of Sb-bearing minerals can also explain the leaching of $\mathrm{Sb}$ as a function of $\mathrm{pH}$. The solubility of stibnite was modelled for sample $\mathrm{SH} 2$, for which the mineralogical analysis showed the occurrence of $2.9 \mathrm{wt} . \%$ of stibnite. Based on the total $\mathrm{Sb}$ concentration in this sample, this would mean that $\mathrm{Sb}$ entirely occurs as stibnite. The solubility of stibnite (taking into account an L/S ratio of $10 \mathrm{l} / \mathrm{kg}$ ) was then modeled at the different $\mathrm{pH}$ values determined during the leaching tests with water and $\mathrm{NaOH}$ - solutions. Based on the modeling, stibnite completely dissolves at pH 7.5 and higher. However, other Sb-containing minerals are oversaturated at alkaline $\mathrm{pH}$, with $\mathrm{Sb}(\mathrm{OH})_{3}$ and Senarmontite $\left(\mathrm{Sb}_{2} \mathrm{O}_{3}\right)$ displaying the highest saturation indices (Supplementary material, Table S4). However, when precipitation of the oversaturated minerals was included in the model, only $\mathrm{Sb}(\mathrm{OH})_{3}$ precipitated. When we compare the amount of dissolved $\mathrm{Sb}$ as found experimentally, with the amount of $\mathrm{Sb}$ that would be dissolved according to the model (Figure $5 \mathrm{a}$ ), we see that the dissolution and precipitation reactions alone are not sufficient to explain the $\mathrm{pH}$-dependent release of $\mathrm{Sb}$. At pH values 7.5 and 8.2, less $\mathrm{Sb}$ is found in solution than predicted by the model.

Besides stibnite, sample $\mathrm{SH} 2$ also contains clay minerals -and feldspars which can play a role in the sorption and desorption of Sb. At alkaline $\mathrm{pH}$ values, Sb occurs as a negatively charged species, which will desorb from negatively charged surfaces of clay minerals and feldspars. The $\mathrm{Sb}$ that is 
released is apparently not precipitated as $\mathrm{Sb}(\mathrm{OH})_{3}$, most likely because of slow reaction kinetics. Besides mineralogy and $\mathrm{pH}$, microorganisms also contribute to the dissolution of Sb-minerals, such as stibnite, and thus contribute to the release of $\mathrm{Sb}(\mathrm{V})$ in groundwater and surface water (Loni et al., 2020). The progressive (chemical and microbial) dissolution of stibnite, followed by microbial oxidation to $\mathrm{Sb}(\mathrm{V})$ decreases the toxicity of $\mathrm{Sb}(\mathrm{III})$ to microorganisms. Moreover, $\mathrm{Sb}(\mathrm{V})$ can be incorporated in goethite (Burton et al. 2020) or in $\mathrm{Sb}(\mathrm{V})$-bearing mopungite $\left(\mathrm{NaSb}(\mathrm{OH})_{6}\right)$ (Multani et al., 2016). In the slag sample, modeling with PHREEQC indicates that the dissolution of cervantite increases with increasing $\mathrm{pH}$, but that $\mathrm{Sb}$ precipitates again as $\mathrm{SbO}_{2}$. At pH values 9.5 and 10.6, a good fit between the model and the experimental results is obtained when only dissolution of cervantite is considered (without precipitation of $\mathrm{SbO}_{2}$ ) (Figure 5b). However, at pH 12.1, the model predicts a much higher release of $\mathrm{Sb}$ than is actually the case (experimental results), which indicates that $\mathrm{Sb}$ most likely precipitates at $\mathrm{pH}$ 12.1. When precipitation is allowed in the model, Sb-concentrations are underestimated by the model. This difference can be explained by slow precipitation and reaction kinetics, Besides the dissolution and precipitation of Sb-bearing minerals, the desorption of $\mathrm{Sb}$ from reactive surfaces (e.g. augite) might also play a role here With respect to As, the release of As from the mine waste and the slag sample was very low, even when the $\mathrm{pH}$ increased up to a pH of 11 . At a pH > 12, 2 to $27 \%$ of the total As-content was released. For the heavy metals, the $\mathrm{pH}$ increase resulted in a decrease of soluble concentrations.

\section{Figure 5 here}

\section{Conclusion}

The present study shows that, when mine waste stored on the site of the Mau Due mine comes into contact with water, it leaches up to $1.7 \%$ of its total Sb content. However, because of the high $\mathrm{Sb}$ content of some of the materials (up to $2.7 \mathrm{wt} . \%$ ), high dissolved Sb concentrations are found in the leachates. Two of the investigated samples (SH2 and SL1) are listed by the EU as absolutely hazardous waste, because of the leaching potential of Sb. Especially in the rainy season, leaching of $\mathrm{Sb}$ from the mine waste and slags can contribute to the dispersion of Sb.

In all samples, an increased release of Sb was observed from $\mathrm{pH} 7.5$ to 12.8. Modeling also indicated that the dissolution of stibnite and re-precipitation as $\mathrm{Sb}(\mathrm{OH})_{3}$ is not the only factor that explains $\mathrm{Sb}$ solubility. Desorption reactions and the incorporation of $\mathrm{Sb}$ in mineral phases are most likely also important factors in the retention and release of $\mathrm{Sb}$ from the waste materials and slags.

As long as the mine is operational, the release of $\mathrm{Sb}$ into the environment surrounding the mine (i.e., surface water, groundwater, soils and air) should be avoided. For the immobilization of Sb, several pathways could be envisaged. Microorganisms can, under natural conditions, also decrease the (mobile) $\mathrm{Sb}(\mathrm{V})$ concentration to some extent via the formation of secondary $\mathrm{Sb}(\mathrm{V})$-bearing minerals (Loni et al., 2020) or through incorporation in Fe(hydr)oxides such as goethite (Burton et al., 2020), which offer new ideas about $\mathrm{Sb}(\mathrm{V})$ (bio)remediation. However, immobilization of $\mathrm{Sb}$ is not sufficient to mitigate the risks posed by the uncovered waste and slag heaps. The waste heaps consist of fine-grained material, that can be prone to wind erosion in the dry season. Therefore, measures to prevent the further dispersion of $\mathrm{Sb}$ and other potentially hazardous elements, both via wind erosion, should be put in place. In order to establish regulations for environmental protection, it is necessary to raise governmental and public awareness. The high 
concentrations of Sb imply an important potential hazard for soils, water bodies, and the food chain, for which appropriate measures are necessary.

Finally, two samples taken from the waste heaps showed Sb concentrations around 1-2 wt\%. Further characterization of mine waste found within the mining site and the slags stored next to the refinery should give more detailed information on the chemical and mineralogical composition of the mine waste, as well as the heterogeneity in the composition. Based on the types (i.e., different mineralogical composition and $\mathrm{Sb}$ content) of mine waste found on site, an investigation on the feasibility of recovering $\mathrm{Sb}$ from these 'waste materials' is recommended.

\section{Acknowledgments}

We are grateful to Le Thi Thuy Van for taking the samples, Tom Vandermeeren for performing the extractions, and Elvira Vassilieva for carrying out the ICP-OES analyses. This work was financed with a KU Leuven Starting Grant (STG/14/010) of V. Cappuyns.

\section{References}

M.R. Alfaro, A. Montero, O.M. Ugarte et al., 2015. Background concentrations and reference values for heavy metals in soils of Cuba. Environ. Monit. Assess. 187, 4198.

https://doi.org/10.1007/s10661-014-4198-3

B.J. Alloway, 2013. Heavy Metals in Soils. Vol. 22. Environmental Pollution. Dordrecht: Springer Netherlands.

E. Álvarez-Ayuso, V. Otones , A. Murciego, A. García-Sánchez, I. Santa Regina, 2012. Antimony, arsenic and lead distribution in soils and plants of an agricultural area impacted by former mining activities. Sci.Total Environ. 439, 35-43. http://dx.doi.org/10.1016/j.scitotenv.2012.09.023

C.G. Anderson, 2012. The Metallurgy of Antimony. Chem. Erde 72, 3-8. https://doi.org/10.1016/j.chemer.2012.04.001

P.M. Ashley, D. Craw, B.P. Graham, D.A. Chappell, 2003. Environmental mobility of antimony around mesothermal stibnite deposits, New South Wales, Australia and southern New Zealand. J. Geochem. Explor. 77, 1-14. https://doi.org/10.1016/S0375-6742(02)00251-0

ATSDR. 2017. Agency for Toxic Substances and Disease Registry. Toxicological profile for antimony. Atlanta, GA: U.S. Department of Health and Human Services, Public Health Service. Retrieved from http://www.atsdr.cdc.gov on 15 January 2019

N. Belzile, Y.W. Chen, Z. Wang, 2001. Oxidation of antimony(III) by amorphous iron and manganese oxyhydroxides. Chem. Geol. 174, 379-387.

J. Bergmann, P. Friedel, R. Kleeberg,1998. BGMN - a new fundamental parameter based Rietveld program for laboratory $X$-ray sources, its use in quantitative analysis and structure investigations. CPD Newsletter, Commission of Powder Diffraction, International Union of Crystallography 20, 5-8.

J. Buschmann, L. Sigg, 2004. Antimony (III) binding to humic substances: influence of $\mathrm{pH}$ and type of humic acid Environ. Sci. Technol. 38, 4535-4541. https://doi.org/10.1021/es0499010

E.D. Burton, K. Hockmann, N. Karimian, 2020. Antimony Sorption to Goethite: Effects of Fe(II)Catalyzed Recrystallization. ACS Earth Space Chem.4, 476-487. 
661 S. Carneado, E. Hernández-Nataren, J.F. López-Sánchez, A. Sahuquillo, 2015. Migration of antimony

662 from polyethylene terephthalate used in mineral water bottles. Food Chem., 166(1), 544-550.

663 https://doi.org/10.1016/j.foodchem.2014.06.041

664 C. Casiot, M. Ujevic, M. Munoz, J.L. Seidel, F. Elbaz-Poulichet, 2007. Antimony and arsenic mobility in 665 a creek draining an antimony mine abandoned 85 years ago (upper Orb basin, France). Appl. Geoch. 666 22(4), 788-798. https://doi.org/10.1016/i.apgeochem.2006.11.007

667 R. Cidu, R. Biddau, E. Dore, A. Vacca, L. Marini, 2014. Antimony in the Soil-water-plant System at the 668 Su Suergiu Abandoned Mine (Sardinia, Italy): Strategies to Mitigate Contamination. Sci Total Environ. 669 497-498, 319-31. https://doi.org/10.1016/j.scitotenv.2014.07.117

670 R. Clemente, W. Hartley, P. Riby, N.M. Dickinson, N.W. Lepp, 2010. Trace element mobility in a 671 contaminated soil two years after field-amendment with a greenwaste compost mulch Environ.

672 Pollut., 158. 1644-1651. https://doi.org/10.1016/j.envpol.2009.12.006

673 A. Courtin-Nomade, O. Rakotoarisoa, H. Bril H., M. Grybos, L. Forestier, F. Foucher M. Kunz, 2012.

674 Weathering of Sb-rich mining and smelting residues: insight in solid speciation and soil bacteria

675 toxicity Chem. Erde-Geochem., 72, 29-39. https://doi.org/10.1016/i.chemer.2012.02.004

676 G.A. Diemar, M. Filella, P. Leverett, P.A. Williams, 2009. Dispersion of antimony from oxidizing ore 677 deposits. Pure Appl. Chem. 81, 1547-1553. https://doi.org/10.1351/PAC-CON-08-10-21

678 Deloitte Sustainability, 2015. Study of Data for a Raw Material System Analysis: Roadmap and Test of 679 the Fully Operational MSA for Raw Materials. Prepared for the European Commission, DG GROW. 680 ISBN 978-92-76-08568-3. Available at https://ec.europa.eu/jrc/en/scientific-tool/msa

681 E.Z. Doan. 2020. Antimony ore production in Vietnam from 2010 to 2018. May 11, 2020. Retrieved 682 from https://www.statista.com/statistics/1003650/vietnam-antimony-ore-production/

683 D. Dupont, S. Arnout, P.T. Jones, K. Binnemans, 2016. Antimony Recovery from End-of-Life Products 684 and Industrial Process Residues: A Critical Review. J. Sustain. Metall. 2, 79-103.

685 https://doi.org/10.1007/s40831-016-0043-y

686 V. Ettler, M. Mihaljevič, O. Šebek, Z. Nechutný, 2007. Antimony availability in highly polluted soils 687 and sediments - a comparison of single extractions. Chemosphere 68, 455-463.

688 https://doi.org/10.1016/j.chemosphere.2006.12.085

689 EU, 1998. Council Directive 98/83/EC on the quality of water intented for human consumption. 690 Adopted by the Council, on 3 November 1998.

691 European Commission, 2017. Study on the review of the list of Critical Raw Materials - Criticality 692 Assessments. Directorate-General for Internal Market, Industry, Entrepreneurship and SMEs. 693 Directorate Industrial Transformation and Advanced Value Chains Unit C.2 - Resource Efficiency 694 and Raw Materials. Luxembourg: Publications Office of the European Union, 2017, 695 https://doi/10.2873/876644

696 EN 12457-2, 2002. Characterisation of waste leaching compliance test for leaching of granular waste 697 materials and sludges - part 2. The European Committee for Standardization (CEN), Brussels.

698 M. E. Essington, M.A. Stewart, 2018. Adsorption of Antimonate, Sulfate, and Phosphate by Goethite: 699 Reversibility and Competitive Effects, Soil Science Society of America Journal, 82(4), 803-814). 
EU, 1998. Council Directive 98/83/EC of 3 November 1998 on the quality of water intended for human consumption, ANNEX I: PARAMETERS AND PARAMETRIC VALUES, PART B: Chemical parameters". EUR-Lex. Retrieved 30 December 2019.

M. Filella, N. Belzile, Y.W. Chen, 2002. Antimony in the environment: a review focused on natural waters: I. Occurrence. Earth Sci. Rev., 57 (1-2), 125-176. https://doi.org/10.1016/S0012$\underline{8252(01) 00070-8}$

H.C. Flynn, A.A. Meharg, P.K. Bowyer, G. I. Paton, 2003. Antimony Bioavailability in Mine Soils. Environ. Pollut. 124 (1), 93-100. https://doi.org/10.1016/S0269-7491(02)00411-6

Z. Fu, F. Wu, C. Mo, Q. Deng, W. Meng, J.P. Giesy, 2016. Comparison of arsenic and antimony biogeochemical behavior in water, soil and tailings from Xikuangshan, China. Sci. Total Environ. 539, 97-104. https://doi.org/10.1016/j.scitotenv.2015.08.146

J. Gál, A. Hursthouse, S. Cuthbert, 2007. Bioavailability of arsenic and antimony in soils from an abandoned mining area, Glendinning (SW Scotland). J. Environ. Sci. Health A, 42, 1263-1274. https://doi.org/10.1080/10934520701435585

P. Ganne, V. Cappuyns, A. Vervoort, L. Buve, R. Swennen, 2006. Leachability of heavy metals and arsenic from slags of metal extraction industry at Angleur (eastern Belgium). Science of the total environment, 356 (1), 69-85. https://doi.org/10.1016/j.scitotenv.2005.03.022

X. Guo, Z. Wu, M. He, X. Meng, X. Jin, N. Qiu, J. Zhang, 2014a. Adsorption of antimony onto iron oxyhydroxides: Adsorption behavior and surface structure. J. Hazard. Mater. 276,339-345.

X. Guo, K. Wang, M. He, Z. Liu, H. Yang, S. Li, 2014b. Antimony smelting process generating solid wastes and dust: characterization and leaching behaviors. J. Environ. Sci. 26, 1549-1556. https://doi.org/10.1016/i.jes.2014.05.022

C.S. Griggs, W.A. Martin, S.L. Larson, G. O'Connnor, G. Fabian, G. Zynda, D. Mackie, 2011. The effect of phosphate application on the mobility of antimony in firing range soils. Sci. Total Environ., 23972403. https://doi.org/10.1016/i.scitotenv.2011.02.043

J.P. Gustafsson. 2013. Visual MINTEQ. Version 3.1: a Windows Version of MINTEQA2, Version 3.1. Available on http://www2.Iwr.kth.se/English/OurSoftware/vminteq/ (accessed on 27.05.2020)

T.H. Hasanin, T. Yamamoto, Y.Okamoto, S. Ishizaka S, Fujiwara T., 2016. A Flow Method for Chemiluminescence Determination of Antimony(III) and Antimony(V) Using a Rhodamine BCetyltrimethylammonium Chloride Reversed Micelle System Following On-Line Extraction. Anal Sci. 32(2), 245-50. https://doi.org/10.2116/analsci.32.245

M.C. He, 2007. Distribution and phytoavailability of antimony at an antimony mining and smelting area, Hunan, China. Environ. Geoch. Health 29, 209-219. https://doi.org/10.1007/s10653-006-9066$\underline{9}$

M.C. He, N.N. Wang, X.J. Long, C.J. Zhang, C.L. Ma, Q.Y. Zhong et al., 2019. Antimony speciation in the environment: recent advances in understanding the biogeochemical processes and ecological effects. J. Environ. Sci. 75, 14-39. https://doi.org/10.1016/i.jes.2018.05.023

Health Canada, 1999. Guidelines for Canadian Drinking Water Quality: Guideline Technical document - Antimony. 10 pp. 
D.S.T. Hjortenkrans, N.S. Mansson, B.G. Bergback, A.V.Haggerud, 2009. Problems with Sb analysis of environmentally relevant samples. Environ. Chem., 6, 153-159. https://doi.org/10.1071/EN08077

X. Hu, X. Guo, M. He, S. Li, 2016. pH-dependent release characteristics of antimony and arsenic from typical antimony-bearing ores. J. Environ Sci., 44, 171-179. https://doi.org/10.1016/i.jes.2016.01.003

A.G. Ilgen, T.P. Trainor. 2012. Sb (III) and Sb (V) sorption onto Al-rich phases: hydrous Al oxide and clay minerals kaolinite KGa-1b and oxidized and reduced nontronite NAU-1. Environ. Sci. Technol., 46, 843-851. https://doi.org/10.1021/es203027v

S. Ishihara, H. Murakami, X. Li, 2011. Indium concentration in zinc ores in plutonic and volcanic environments. Examples at the Dulong and Dachang mines, South China. Bull. Geol. Surv. Japan 62, 259-272. https://doi.org/10.9795/bullgsi.62.259

S. Ishihara, P.T. Xuan, 2013. Distribution of Some Ore Metals around the Mau Due Stibnite Deposits, Northernmost Vietnam. Bull. Geol. Surv. Japan 64: 51-57. https://doi.org/10.9795/bullgsj.64.51

S.G. Johnston, W.W. Bennet, N. Dorian, K. Hockmann, N. Karimian, E.D. Burton, 2020. Antimony and arsenic speciation, redox-cycling and contrasting mobility in a mining-impacted river system. Science of The Total Environment, 710: 136354. https://doi.org/10.1016/j.scitotenv.2019.136354

L'. Jurkovič, J. Majzlan, E. Hiller, T. Klimko, B. Voleková-Lalinská, E. Hiller, P. Šottník, J. Göttlicher, R. Steininger, 2019. Natural attenuation of antimony and arsenic in soils at the abandoned Sb-deposit Poproč, Slovakia. Environ Earth Sci 78, 672. https://doi.org/10.1007/s12665-019-8701-6

W.R. Kammin, M.J. Brandt, 1988. ICP-OES evaluation of microwave digestion. Spectroscopy, 5(3), 49-55.

N. Karimian, S.G. Johnston, E.D. Burton, 2018. Iron and sulfur cycling in acid sulfate soil wetlands under dynamic redox conditions: A review. Chemosphere, 197: 803-816.

https://doi.org/10.1016/i.chemosphere.2018.01.096

A.R. Kumar, P. Riyazuddin, 2007. Non-chromatographic hydride generation atomic spectrometric techniques for the speciation analysis of arsenic, antimony, selenium, and tellurium in water samples - a review Int. J. Environ. Anal. Chem. 87(7), 469-500.

https://doi.org/10.1080/03067310601170415

C.R. Lehr, D.R. Kashyap, T.R. McDermott, 2007. New insights into microbial oxidation of antimony and arsenic. Appl. Environ. Microbiol.73, 2386-2389. https://doi: 10.1128/AEM.02789-06

A. Leuz, H. Monch, C.A. Johnson, 2006. Sorption of Sb (III) and Sb (V) to goethite: Influence on Sb (III) oxidation and mobilization. Environ. Sci. Technol. 40, 7277-7282.

https://doi.org/10.1021/es061284b

K. Lewińska, A. Karczewska, M. Siepak, B.ernard Gałka; 2018. The Release of Antimony from Mine Dump Soils in the Presence and Absence of Forest Litter. Int. J. Environ Res. Public Health. 15(12), 2631. https://doi.org/10.3390/ijerph15122631

Li, W., Cook, N.J., Xie, G., C. L. Ciobanu, J-W. Li \& Z.-Y. Zhang, 2018. Textures and trace element signatures of pyrite and arsenopyrite from the Gutaishan Au-Sb deposit, South China. Miner Deposita 54, 591-610. https://doi.org/10.1007/s00126-018-0826-0 
P.C. Loni, M. Wu, W. Wang, H. Wang, L. Ma, C. Liu, Y. Song, H.T. O., 2020. Mechanism of microbial dissolution and oxidation of antimony in stibnite under ambient conditions. J. Hazard. Mater. 385, 121561. https://doi.org/10.1016/j.jhazmat.2019.121561

J. Majzlan, M. Stevko, M., T. Lanczos, 2016. Soluble secondary minerals of antimony in Pezinok and Kremnica (Slovakia) and the question of mobility or immobility of antimony in mine waters. Environ. Chem. 13, 927-935. https://doi.org/10.1071/EN16013

E. Mariussen, 2012. Analysis of antimony (Sb) in environmental samples. Norwegian Defence Research Establishment (FFI), 28 February 2012, 2 FFI-rapport 2012/00347, ISBN 978-82-464-2049-3, $27 \mathrm{pp}$.

K. Macgregor, G. MacKinnon, J.G. Farmer, M.C. Graham, 2015. Mobility of Antimony, Arsenic and Lead at a Former Antimony Mine, Glendinning, Scotland. Sci.Total Environ. 529, 213-22. https://doi.org/10.1016/j.scitotenv.2015.04.039

L. Mbadugha, D. Cowper, S. Dossanov, G.I. Paton, 2020. Geogenic and anthropogenic interactions at a former Sb mine: environmental impacts of As and Sb. Environ. Geochem. Health. https://doi.org/10.1007/s10653-020-00652-wS. Mitsunobu, T. Harad, Y. Takahashi, 2006. Comparison of antimony behavior with that of arsenic under various soil redox conditions. Environ. Sci. Technol. 40, 7270-7276. https://doi.org/10.1021/es060694x

R.S. Multani, T. Feldmann, G.P. Demopoulos, 2016. Antimony in the metallurgical industry: a review of its chemistry and environmental stabilization options. Hydrometallurgy., 164, 141-153. https://doi.org/10.1016/j.hydromet.2016.06.014

A.M. Murciego, A.G. Sanchez, M.A.R. Gonzalez, E.P. Gil, C.T. Gordillo, J.C. Fernandez, T.B. Triguero, 2007. Antimony distribution and mobility in topsoils and plants (Cytisus striatus, Cistus ladanifer and Dittrichia viscosa) from polluted Sb-mining areas in Extremadura (Spain). Environ.Poll. 145, 15-21. https://doi.org/10.1016/i.envpol.2006.04.004

Y.M. Nakamaru, F.J. Martín Peinado, 2017. Effect of soil organic matter on antimony bioavailability after the remediation process. Environ. Pollut., 228, 425-432.

https://doi.org/10.1016/j.envpol.2017.05.042

M.J. Nash, J.E. Maskall, S.J. Hill, 2000. Methodologies for determination of antimony in terrestrial environmental samples. J. Environ. Monit., 2, 97-109. https://doi.org/10.1039/a907875d

Z. Ning, T. Xiao, E. Xiao, 2015. Antimony in the Soil-Plant System in an Sb Mining/Smelting Area of Southwest China. Int. J. Phytorem. 17(11), 1081-1089. https://doi.org/10.1080/15226514.2015.1021955

G. Okkenhaug, Y.G. Zhu, L. Luo, M. Lei, X. Li, J. Mulder, 2011. Distribution, speciation and availability of antimony (Sb) in soils and terrestrial plants from an active Sb mining area. Environ. Pollut., 159 (2011), 2427-2434. https://doi.org/10.1016/i.envpol.2011.06.028

G. Oprea, A. Michnea, C. Mihali, M. Senilă, C. Roman, S. Jelea, C. Butean, C. Barz, 2010. Arsenic and Antimony Content in Soil and Plants from Baia Mare Area, Romania. Am. J. Environ. Sci. 6(1), 33-40. https://doi.org/10.3844/ajessp.2010.33.40 
816 C. Pérez-Sirvent, M.J. Martínez-Sánchez, S. Martínez-López, M. Hernández-Córdoba, 2011. Antimony

817 distribution in soils and plants near an abandoned mining site. Microchem. J. 97, 52-5.

818 https://doi.org/10.1016/j.microc.2010.05.009

819 A. Pierart, M. Shahid, N. Séjalon-Delmas, C. Dumat, 2015. Antimony Bioavailability: Knowledge and

820 Research Perspectives for Sustainable Agricultures. J. Hazard. Mater. 289, 219-34.

821 https://doi.org/10.1016/j.jhazmat.2015.02.011

822 B. Pahlavapour, M. Thompson, L. Thorne, 1980. Simultaneous determination of trace concentrations

823 of arsenic, antimony and bismuth in soils and sediments by volatile hydride generation and

824 inductively coupled plasma emission spectrometry. Analyst, 105, 756 -761.

825 https://doi.org/10.1039/AN9800500756

826 J.-H. Park, S.-J. Kim, J.S. Ahn, D.-H. Lim, Y.-S. Han, 2018. Mobility of multiple heavy metalloids in

827 contaminated soil under various redox conditions: effects of iron sulfide presence and phosphate

828 competition. Chemosphere, 197, 344-352. https://doi.org/10.1016/i.chemosphere.2018.01.065

829 D.L. Parkhurst, C.A.J. Appelo, 1999. User's guide to PHREEQC (version 3) - a computer program for

830 speciation, batch-reaction, one-dimensional transport and inverse geochemical calculations.

831 W. Qi, J. Cao, 1991. Background concentration of antimony in Chinese soils (In Chinese). Soil Bulletin

$832 \quad 22,209-210$.

833 A.B. Radková, H.E. Jamieson, K.M. Campbell, 2020. Antimony mobility during the early stages of

834 stibnite weathering in tailings at the Beaver Brook Sb deposit. Newfoundland. Appl. Geochem. 55,

835 104528. https://doi.org/10.1016/j.apgeochem.2020.104528

836 S. Rakshit, D. Sarkar, R. Datta. 2015. Surface complexation of antimony on kaolinite. Chemosphere,

837 119, 349-354. https://doi.org/10.1016/j.chemosphere.2014.06.070

838 A. J. Roper, P. A. Williams, and M. Fillela, 2012. 'Secondary Antimony Minerals: Phases That Control

839 the Dispersion of Antimony in the Supergene Zone'. Chem.r Erde - Geochem.72, 9-14.

840 https://doi.org/10.1016/i.chemer.2012.01.005

841 A. Rouwane, M. Rabiet, M. Grybos, G. Bernard, G. Gibaud, 2016. Effects of $\mathrm{NO}_{3}{ }^{-}$and $\mathrm{PO}_{4}{ }^{3-}$ on the

842 release of geogenic arsenic and antimony in agricultural wetland soil: a field and laboratory

843 approach. Environ. Sci. Pollut. Res. 23, 4714-4728. https://doi.org/10.1007/s11356-015-5699-5

844 R. Salminen, M.J. Batista, M. Bidovec, A. Demetriades, B. De Vivo, W. De Vos, M. Duris, A. Gilucis, V.

845 Gregorauskiene, J. Halamic, P. Heitzmann, A. Lima, G. Jordan, G. Klaver, P. Klein, J. Lis, J. Locutura, K.

846 Marsina, A. Mazreku, P.J. O'Connor, S.Å. Olsson, R.-T. Ottesen, V. Petersell, J.A. Plant, S. Reeder, I.

847 Salpeteur, H. Sandström, U. Siewers, A. Steenfelt, T. Tarvainen (2005) Geochemical Atlas of Europe.

848 Part 1: Background Information, Methodology and Maps Geological Survey of Finland, Espoo (2005)

849 (526 pages, 36 figures, 362 maps)

850 M.J. Serafimovska, S. Arpadjan, T. Stafilov, K. Tsekova, 2013. Study of the antimony species

851 distribution in industrially contaminated soils. J. Soils Sed.13, 294-303.

852 https://doi.org/10.1007/s11368-012-0623-9

853 T. Sh, C. Liu, C. Feng, 2012. Solubility, toxicity and sorption of antimony from smelter release. J.

854 Geochem. Explor., 118, 14-18. https://doi.org/10.1016/j.gexplo.2012.03.007 
Statista, 2019. Major countries in worldwide antimony mine production from 2015 to 2019 (in metric tons). Retrieved from https://www.statista.com/statistics/264958/antimony-production/ on 13 January 2020.

S. Steely, D. Amarasiriwardena, B. Xing, 2007. An investigation of inorganic antimony species and antimony associated with soil humic acid molar mass fractions in contaminated soils. Environ. Poll. 148, 590-598. https://doi.org/10.1016/i.envpol.2006.11.031

S. Sundar, J. Chakravarty, 2010. Antimony toxicity. Int. J. Environ. Res. Public Health 7(12), 42674277. https://doi.org/10.3390/ijerph7124267

K. Telford, W. Maher, F. Krikowa, S. Foster, 2008. Measurement of total antimony and antimony species in mine contaminated soils by ICPMS and HPLC-ICPMS. J. Environ. Monit., 10(1),136-140. https://doi.org/10.1039/B715465H

M. Tighe, P. Ashley, P. Lockwood, S. Wilson, 2005a. Soil, water and pasture enrichment of antimony and arsenic within a coastal floodplain system. Sci. Total Environ. 347 175-186. https://doi.org/10.1016/j.scitotenv.2004.12.008

M. Tighe, P. Lockwood, S. Wilson, 2005b. Adsorption of antimony(V) by floodplain soils, amorphous iron(III) hydroxide and humic acid. J. Environ. Monit.7 1177-1185. https://doi.org/10.1039/B508302H

M. Tighe, P. Lockwood, S. Wilson, L. Lisle, 2004. Comparison of digestion methods for ICP-OES analysis of a wide range of analytes in heavy metal contaminated soil samples with specific reference to arsenic and antimony. Comm. Soil Sci. Plant Anal. 35 (9-10), 1369-1385. http://dx.doi.org/10.1080/00103620701378441

USEPA, 2018. United States Environmental Protection Agency, 2018 Edition of the Drinking Water Standards and Health Advisories. Retrieved from: https://www.epa.gov/sites/production/files/201803/documents/dwtable2018.pdf (02.02.2020)

M. Verbeeck, R. Warrinnier, J.P. Gustafsson, Y. Thiry, E. Smolders, 2019. Soil organic matter increases antimonate mobility in soil: an $\mathrm{Sb}(\mathrm{OH}) 6$ sorption and modelling study. Appl. Geochem. 104, 33-41. https://doi.org/10.1016/j.scitotenv.2020.138874

M. Verbeeck, Y. Thiry Y, E. Smolders, 2020a. Soil organic matter affects arsenic and antimony sorption in anaerobic soils. Environ Pollut. 257, 113566.

https://doi.org/10.1016/i.envpol.2019.113566

M. Verbeeck, Thiry Y, E. Smolders, 2020b. Antimonate sorption in soils increases with ageing. Eur. J. Soil Sci. 71, 55-59. https://doi.org/10.1111/ejss.12845

V. Ettler, M. Mihaljevič , O. Šebek, Z. Nechutný, 2007. Antimony Availability in Highly Polluted Soils and Sediments - A Comparison of Single Extractions. Chemosphere 68 (3), 455-463. https://doi.org/10.1016/i.chemosphere.2006.12.085

D.H. Vu, X.M/ Biu, H.A. Le, 2012. The Effect of Mining Exploitation on Environment in Vietnam. China-ASEAN Mining Cooperation Forum and Exhibition 2012.

X. Wang, M. He, J. Xie et al. Heavy metal pollution of the world largest antimony mine-affected agricultural soils in Hunan province (China). J Soils Sediments 10, 827-837 (2010).

https://doi.org/10.1007/s11368-010-0196-4 
895 WHO, 2003. Antimony in Drinking-water Background document for development of WHO Guidelines

896 for Drinking-water Quality. WHO/SDE/WSH/03.04/74, World Health Organization, Geneva,

897 Switserland.

898 N.J. Wilson, D. Craw, K.A. Hunter, 2004. Antimony distribution and environmental mobility at an

899 historic antimony smelter site, New Zealand. Environ. Pollut. 129, 257- 266.

900 https://doi.org/10.1016/i.envpol.2003.10.014

901 S.C. Wilson, P.V. Lockwood, P.M. Ashley, M. Tighe, 2010. The chemistry and behaviour of antimony

902 in the soil environment with comparisons to arsenic: a critical review. Environ. Pollut. 158; 1169-

903 1181. https://doi.org/10.1016/i.envpol.2009.10.045

904 P.T. Xuan. 2011. Research on the influence of exploiting slag heaps and metal mineral processing on 905 environment and human being health and put forward damage reducing methods (pp. 159-182).

906 Vietnam Ministry of Science and Technology: Vietnam Academy of Science and Technology.

907 Y. Yuan, M. Xiang, C. Liu, B.K.G. Theng, 2017. Geochemical characteristics of heavy metal

908 contamination induced by a sudden wastewater discharge from a smelter. J. Geochem. Explor. 176,

909 33-41. https://doi.org/10.1016/j.gexplo.2016.07.005 


\section{$910 \quad$ Figure and table captions}

911

912 Figures

913 Figure 1 Representation of the sampling locations (aerial photographs from Google maps (2020),

914 pictures from Le Thi Thuy Van).

915 Figure 1 Soluble Sb concentrations released from the slag (SL) and mine waste (SH) and soil (SO)

916 samples with water (after 2 and $24 \mathrm{~h}$ of shaking) and with a $0.1 \mathrm{~mol} / \mathrm{I} \mathrm{Na} 2 \mathrm{HPO}_{4} \cdot 2 \mathrm{H}_{2} \mathrm{O}$ solution.

917 Average \pm standard deviation of 2 replicates. The number on top of each bar is the $\mathrm{pH}$ of the solution

918 after extraction. For the soil samples, Sb concentrations obtained after the EN 12457-2 test were

919 below detection limit.

920 Figure 2 Release of $\mathrm{Sb}$ as a function of $\mathrm{pH}$ from a mine waste (SH2), slag (SL1) and soil (SO1) sample.

921 For comparison, the release of $\mathrm{Sb}$ with the $\mathrm{Na}_{2} \mathrm{HPO}_{4} \cdot 2 \mathrm{H}_{2} \mathrm{O} 0.1 \mathrm{~mol} / \mathrm{l}$ solution is also indicated.

922 Average of two replicates. When error bars are not visible, they are smaller than the marker.

923 Figure 3 Comparison of the multi-acid digestion method and the $\mathrm{LiBO}_{2}$ fusion for $\mathrm{Sb}$ and Fe. Average

924 of 2 replicates

925 Figure 4 dissolved $\mathrm{Sb}$ concentrations as a function of $\mathrm{pH}$ : experimental and modelled results for (a)

926 sample SH2 and (b) sample SL1

927

928 Tables

929 Table 1 Operational parameters of the different extractions

930 Table 2 Elemental composition of the samples investigated in this study. Trace elements were 931 determined after multi-acid digestion; major elements were determined with $\mathrm{LiBO}_{2}$ fusion.

932 Table 3 Antimony concentrations in soils impacted by mining and smelting activities reported in

933 literature (non-limiting overview, in chronological order). The different digestion and analytical

934 techniques are also given. 

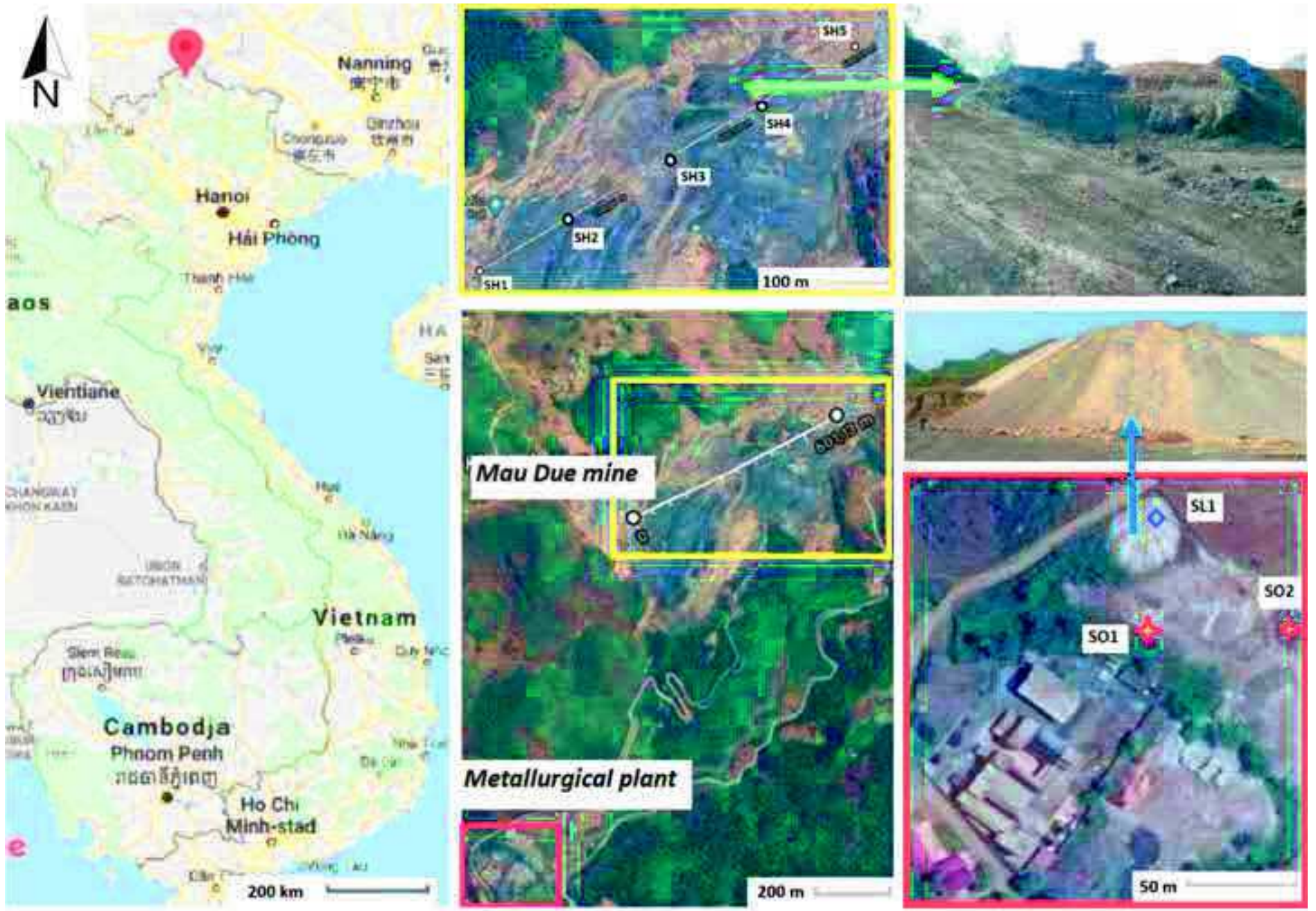


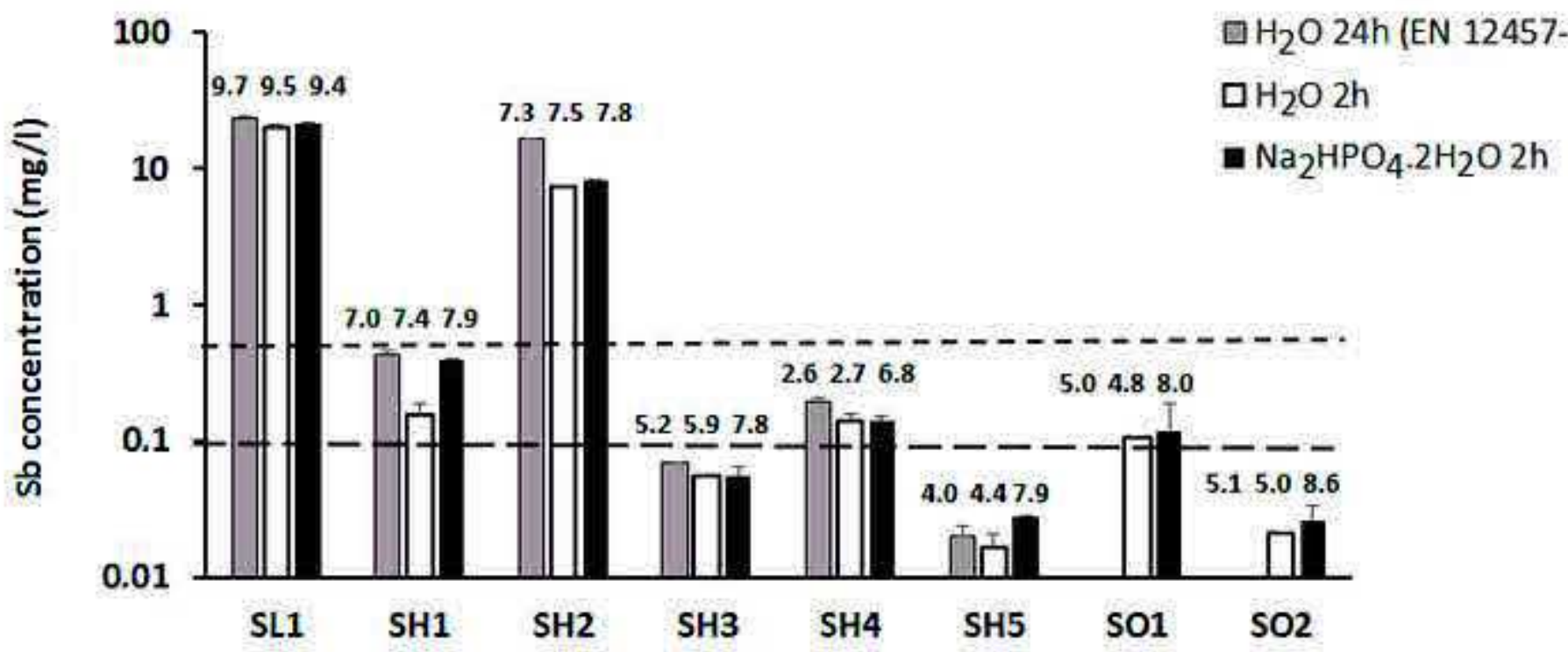



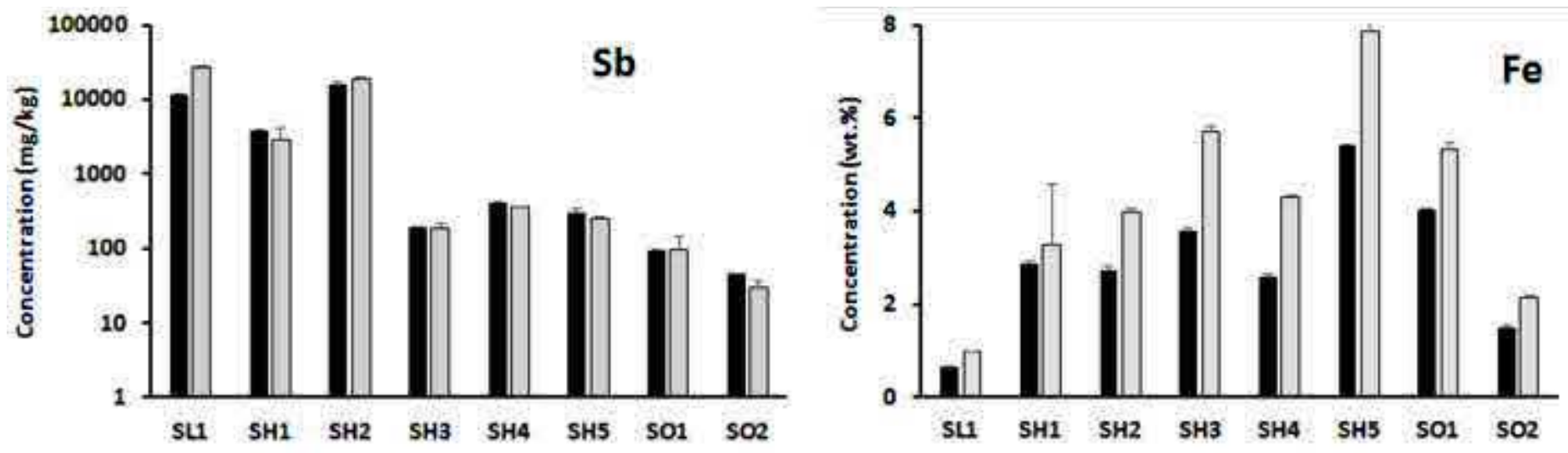

a mult-acid digestion $\square \mathrm{LiBO}_{2}$ fusion 

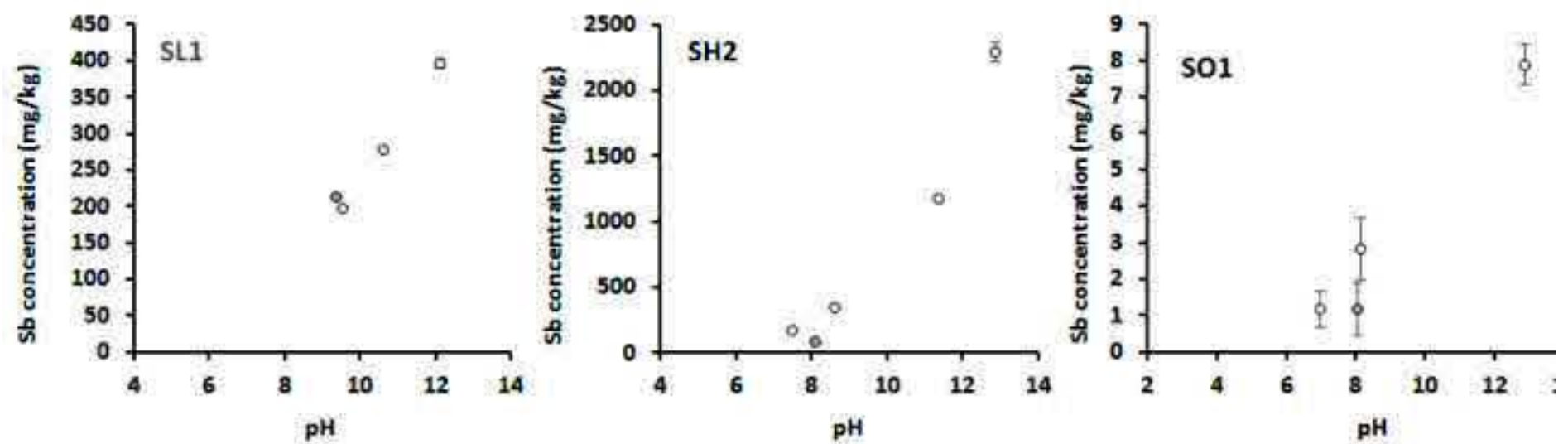

o water en dituted $\mathrm{NaOH}$ solutions: $\quad . \mathrm{Na}_{2} \mathrm{HPO}_{4} \cdot 2 \mathrm{H}_{2} \mathrm{O} 0.1 \mathrm{~mol} / \mathrm{l}$ 
(a)

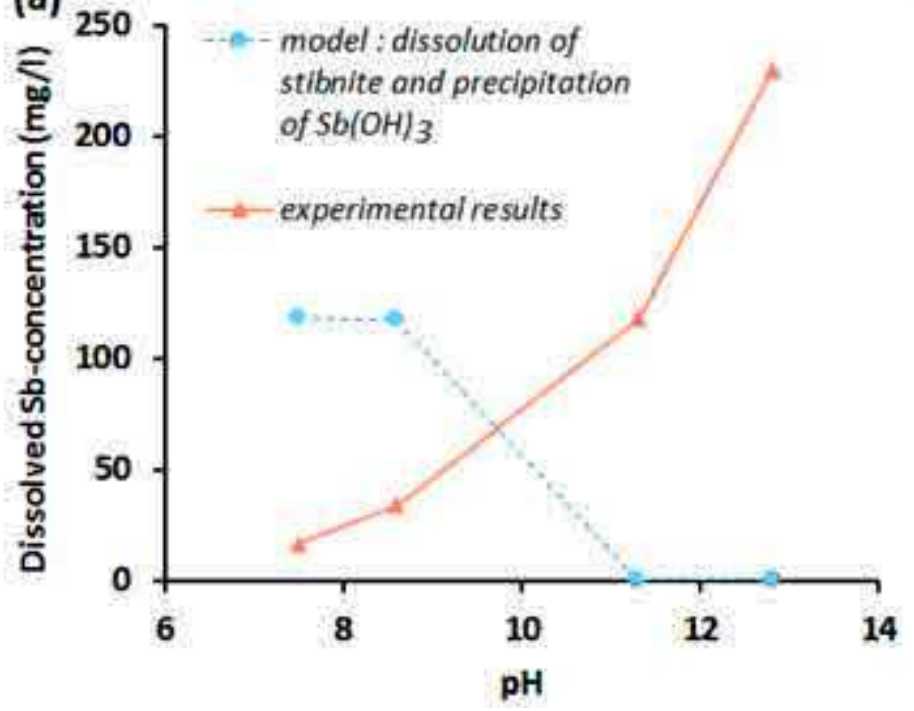

(b)

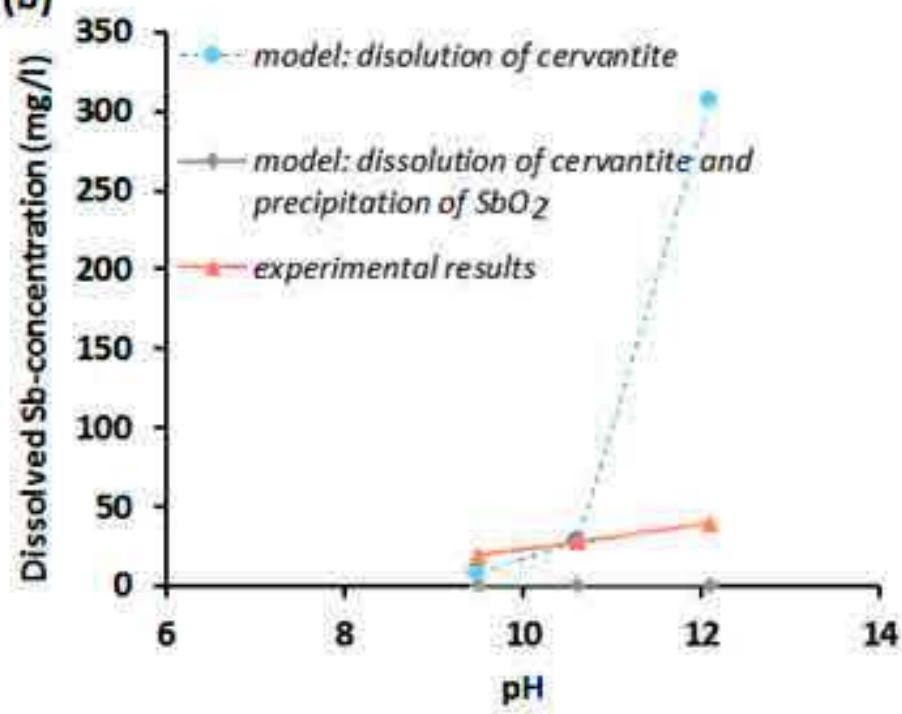


Table 1 Operational parameters of the different extractions

\begin{tabular}{|l|l|l|l|}
\hline Extraction & L/S ratio & Extraction time & Reference \\
\hline Demineralised water & $10 \mathrm{l} / \mathrm{kg}$ & $2 \mathrm{~h}$ & Ettler et al. (2007) \\
\hline $\mathrm{Na}_{2} \mathrm{HPO}_{4} .2 \mathrm{H}_{2} \mathrm{O} 0.1 \mathrm{~mol} / \mathrm{l}$ & $10 \mathrm{l} / \mathrm{kg}$ & $2 \mathrm{~h}$ & Ettler et al. (2007) \\
\hline $\mathrm{NaOH} 0.005,0.01$, and $0.1 \mathrm{~mol} / \mathrm{l}$ & $10 \mathrm{l} / \mathrm{kg}$ & $24 \mathrm{~h}$ & This work \\
\hline Demineralised water & $10 \mathrm{l} / \mathrm{kg}$ & $24 \mathrm{~h}$ & EN12457-2 (2002). \\
\hline
\end{tabular}


Table 2 Elemental composition of the samples investigated in this study. Trace elements were determined after multi-acid digestion; major elements were determined after $\mathrm{LiBO}_{2}$ fusion.

\begin{tabular}{|c|c|c|c|c|c|c|c|c|c|c|c|c|c|c|c|c|c|c|c|c|c|c|c|}
\hline \multirow[b]{2}{*}{$\mathrm{SH} 1$} & \multicolumn{3}{|c|}{$\begin{array}{c}\text { As } \\
\mathrm{mg} / \mathrm{kg}\end{array}$} & \multicolumn{3}{|c|}{$\begin{array}{c}\mathrm{Cd} \\
\mathrm{mg} / \mathrm{kg}\end{array}$} & \multicolumn{3}{|c|}{$\begin{array}{c}\mathrm{Cr} \\
\mathrm{mg} / \mathrm{kg}\end{array}$} & \multicolumn{3}{|c|}{$\begin{array}{c}\mathrm{Cu} \\
\mathrm{mg} / \mathrm{kg}\end{array}$} & \multicolumn{3}{|c|}{$\begin{array}{c}\mathrm{Ni} \\
\mathrm{mg} / \mathrm{kg}\end{array}$} & \multicolumn{3}{|c|}{$\begin{array}{c}\mathrm{Pb} \\
\mathrm{mg} / \mathrm{kg}\end{array}$} & \multicolumn{3}{|c|}{$\begin{array}{c}\mathrm{Sb} \\
\mathrm{mg} / \mathrm{kg}\end{array}$} & \multicolumn{2}{|c|}{$\begin{array}{c}\mathrm{Zn} \\
\mathrm{mg} / \mathrm{kg}\end{array}$} \\
\hline & 115 & & 3.3 & 9.0 & \pm & 0.14 & 57 & \pm & 0.1 & 124 & \pm & 0.4 & 112 & \pm & 1.5 & 31 & \pm & 2.71 & 3785 & \pm & 112 & $427 \pm$ & 107 \\
\hline $\mathrm{SH} 2$ & 130 & \pm & 5.3 & 7.3 & \pm & 0.44 & 88 & \pm & 1.5 & 55 & \pm & 4.6 & 95 & \pm & 1.8 & 23 & \pm & 1.34 & 15699 & \pm & 1031 & $345 \pm$ & 17 \\
\hline $\mathrm{SH} 3$ & 167 & \pm & 3.1 & 5.0 & \pm & 1.43 & 141 & \pm & 0.8 & 75 & \pm & 10 & 91 & \pm & 2.7 & 26 & \pm & 0.76 & 191 & \pm & 0.6 & $430 \pm$ & 100 \\
\hline $\mathrm{SH} 4$ & 114 & \pm & 3.6 & 1.3 & \pm & 0.04 & 59 & \pm & 0.6 & 179 & \pm & 7.4 & 65 & \pm & 1.8 & 39 & \pm & 0.93 & 407 & \pm & 16 & $33 \pm$ & 1.6 \\
\hline SH5 & 54 & \pm & 3.2 & 1.8 & \pm & 0.16 & 116 & \pm & 0.4 & 69 & \pm & 0.2 & 55 & \pm & 0.1 & 37 & \pm & 0.43 & 299 & \pm & 50 & $149 \pm$ & 1.0 \\
\hline SL1 & 10 & \pm & 1.5 & 1.1 & \pm & 0.14 & 26 & \pm & 0.3 & 25 & \pm & 1.3 & 19 & \pm & 0.3 & 5 & \pm & 0.02 & 11522 & \pm & 317 & $115 \pm$ & 11 \\
\hline SO1 & 244 & \pm & 1.0 & 1.0 & \pm & 0.02 & 94 & \pm & 1.1 & 41 & \pm & 0.4 & 15 & \pm & 0.9 & 21 & \pm & 0.01 & 47 & \pm & 13 & $36 \pm$ & 0.1 \\
\hline \multirow[t]{2}{*}{ SO2 } & 38 & \pm & 0.6 & 0.4 & \pm & 0.00 & 52 & \pm & 4.9 & 23 & \pm & 0.6 & 14 & \pm & 0.7 & 22 & \pm & 1.76 & 95 & \pm & 1.7 & $26 \pm$ & 0.7 \\
\hline & \multicolumn{3}{|c|}{$\begin{array}{c}\text { Al } \\
\text { wt.\% }\end{array}$} & \multicolumn{3}{|c|}{$\begin{array}{c}\text { Ca } \\
\text { wt.\% }\end{array}$} & \multicolumn{3}{|c|}{$\begin{array}{c}\text { Fe } \\
\text { wt.\% }\end{array}$} & \multicolumn{3}{|c|}{$\begin{array}{c}\text { K } \\
\text { wt.\% }\end{array}$} & \multicolumn{3}{|c|}{$\begin{array}{c}\mathrm{Mg} \\
\text { wt.\% }\end{array}$} & \multicolumn{3}{|c|}{$\begin{array}{c}\text { Si } \\
\text { wt.\% }\end{array}$} & \multicolumn{3}{|c|}{$\begin{array}{c}\mathrm{S} \\
\mathrm{mg} / \mathrm{kg}\end{array}$} & \multicolumn{2}{|c|}{$\mathrm{pH}$} \\
\hline $\mathrm{SH} 1$ & 21.67 & \pm & 0.91 & 2.20 & \pm & 0.087 & 5.71 & \pm & 0.11 & 5.06 & \pm & 0.17 & 1.75 & \pm & 0.13 & 28.0 & \pm & 1.62 & 26500 & \pm & $2<4$ & $7.0 \pm$ & 0.01 \\
\hline $\mathrm{SH} 2$ & 17.58 & \pm & 0.91 & 0.10 & \pm & 0.003 & 4.30 & \pm & 0.03 & 4.75 & \pm & 0.21 & 1.27 & \pm & 0.06 & 34.3 & \pm & 1.48 & 34900 & \pm & 1890 & $7.3 \pm$ & 0.05 \\
\hline $\mathrm{SH} 3$ & 19.11 & \pm & 0.76 & 1.11 & \pm & 0.049 & 7.87 & \pm & 0.33 & 4.47 & \pm & 0.17 & 2.23 & \pm & 0.08 & 29.3 & \pm & 1.00 & 22100 & \pm & 537 & $5.2 \pm$ & 0.28 \\
\hline $\mathrm{SH} 4$ & 16.28 & \pm & 0.52 & 0.02 & \pm & 0.002 & 5.32 & \pm & 0.14 & 2.82 & \pm & 0.08 & 0.65 & \pm & 0.02 & 35.6 & \pm & 0.95 & 21700 & \pm & 208 & $2.6 \pm$ & 0.02 \\
\hline SH5 & 18.97 & \pm & 0.10 & 0.01 & \pm & 0.003 & 2.15 & \pm & 0.02 & 4.64 & \pm & 0.05 & 1.06 & \pm & 0.00 & 38.5 & \pm & 0.72 & 8480 & \pm & 40 & $4.0 \pm$ & 0.01 \\
\hline SL1 & 2.23 & \pm & 0.00 & 3.21 & \pm & 0.050 & 0.99 & \pm & 0.01 & 0.31 & \pm & 0.00 & 1.41 & \pm & 0.03 & 44.1 & \pm & 0.42 & 1550 & \pm & 8 & $9.5 \pm$ & 0.02 \\
\hline SO1 & 5.70 & \pm & 0.35 & 7.33 & \pm & 2.65 & 3.26 & \pm & 1.33 & 1.88 & \pm & 0.83 & 4.33 & \pm & 1.57 & 19.8 & \pm & 6.99 & 97 & \pm & 1 & $5.0 \pm$ & 0.07 \\
\hline SO2 & 11.92 & \pm & 0.38 & 7.66 & \pm & 0.14 & 3.99 & \pm & 0.07 & 2.90 & \pm & 0.07 & 4.21 & \pm & 0.07 & 24.2 & \pm & 0.64 & 47 & \pm & 4 & $4.8 \pm$ & 0.15 \\
\hline
\end{tabular}


Table 3 Antimony concentrations in soils impacted by mining and smelting activities reported in literature (non-limiting overview, in chronological order). The different digestion and analytical techniques are also given.

\begin{tabular}{|c|c|c|c|c|}
\hline Location & Source of Sb & $\begin{array}{l}\text { Sb concentration } \\
\text { in soil }\end{array}$ & Method of analysis & reference \\
\hline Soils around five historic mining areas in the UK & Mining area $(\mathrm{Cu}, \mathrm{Pb}, \mathrm{Zn}, \mathrm{As}$, and $\mathrm{Sb})$ & $0.5-40.6 \mathrm{mg} / \mathrm{kg}$ & $\begin{array}{l}\mathrm{HG}-\mathrm{FAAS} \text { analysis after digestion with } \mathrm{HClO}_{4}, \\
\mathrm{HNO}_{3}, \mathrm{HCl}\end{array}$ & Flynn et al. (2003) \\
\hline Forests and tilled soils, Pribram, Czech Republic & $\begin{array}{l}\text { Mining, Sb mineralisation in Pb-Ag- } \\
\mathrm{Zn} \text { mineralization }\end{array}$ & $7.72-705 \mathrm{mg} / \mathrm{kg}$ & $\begin{array}{l}\text { ICP-MS analysis after acid digestion with } \\
\mathrm{HClO}_{4} / \mathrm{HF}\end{array}$ & Ettler et a. (2007) \\
\hline Soils in and around the mining area, Glendinning, Scotland & $\begin{array}{l}\text { Mining, polymetallic mineralisation } \\
\text { including stibnite }\end{array}$ & $\begin{array}{l}14.0-673 \mathrm{mg} / \mathrm{kg} \\
10.3-1200 \mathrm{mg} / \mathrm{kg}\end{array}$ & $\begin{array}{l}\text { ICP-AES analysis after microwave Aqua Regia } \\
\text { destruction }\end{array}$ & Gal et al. (2007) \\
\hline Topsoils, Extremadura, Spain & Sb-mining area & $14.3-5180 \mathrm{mg} / \mathrm{kg}$ & INAA & $\begin{array}{l}\text { Murciego et al. } \\
\text { (2007). }\end{array}$ \\
\hline Soils from a mining site, Hunan, southwest China & Xikuangshan Sb mine & $10-2159 \mathrm{mg} / \mathrm{kg}$ & AFS analysis after Aqua Regia digestion & Wang (2009) \\
\hline Garden and Industrial soils, Baia Mare, Romania & $\begin{array}{l}\text { Area contaminated by dust from } \\
\text { metallurgical plants }\end{array}$ & $0.85-40.06 \mathrm{mg} / \mathrm{kg}$ & $\begin{array}{l}\text { ICP-AES analysis after hotplate Aqua Regia } \\
\text { destruction }\end{array}$ & Oprea et al (2010) \\
\hline $\begin{array}{l}\text { Soil samples (B horizon) in the vicinity of the Bayley Park } \\
\text { Sb prospect near Armidale, NSW, Australia }\end{array}$ & Sb-mineralisation area (no mining) & Up to $150 \mathrm{mg} / \mathrm{kg}$ & Not mentioned & Diemar et al. (2009) \\
\hline Technosols with pH values of 3.5-7.0 Poproč, Slovakia & abandoned Sb-deposit Poproč & $13.4-5757 \mathrm{mg} / \mathrm{kg}$ & $\begin{array}{l}\text { ICP-OES and ICP-MS analysis after acid } \\
\text { digestion }\end{array}$ & \begin{tabular}{|l|}
$\begin{array}{l}\text { Jurkovic et al. } \\
(2010)\end{array}$ \\
\end{tabular} \\
\hline Soils from Sierra Minera, Murcia, Spain & & $5-40 \mathrm{mg} / \mathrm{kg}$ & $\begin{array}{l}\mathrm{HG}-\mathrm{AFS} \text { analysis after microwave digestion } \\
\text { with } \mathrm{HF} / \mathrm{HNO}_{3}\end{array}$ & $\begin{array}{l}\text { Pérez-Sirvent et al. } \\
(2011)\end{array}$ \\
\hline $\begin{array}{l}\text { Soils from a mining site Xikuangshan, } \\
\text { southwest China }\end{array}$ & Active Sb mining area & $527-11798 \mathrm{mg} / \mathrm{kg}$ & $\begin{array}{l}\mathrm{HG}-\mathrm{ICP}-\mathrm{OES} \text { analysis after closed microwave } \\
\mathrm{HNO}_{3} / \mathrm{HF} \text { digestion }\end{array}$ & $\begin{array}{l}\text { Okkenhaug et al. } \\
(2011)\end{array}$ \\
\hline Agricultural soils, Zamora, Spain & $\begin{array}{l}\text { Mining, hydrothermal } \mathrm{Pb}-\mathrm{Sb}-\mathrm{Ag}- \\
\text { rich deposit }\end{array}$ & $14.1-324 \mathrm{mg} / \mathrm{kg}$ & $\begin{array}{l}\text { ICP-AES analysis after microwave Aqua Regia } \\
\text { destruction }\end{array}$ & $\begin{array}{l}\text { Álvarez-Ayuso et al. } \\
\text { (2012) }\end{array}$ \\
\hline Industrially polluted areas in Bulgaria end Macedonia & & $2.5-105 \mathrm{mg} / \mathrm{kg}$ & $\begin{array}{l}\text { ETAAS analysis after hot plate digestion with } \\
\mathrm{HNO}_{3} / \mathrm{HCl} / \mathrm{HF}\end{array}$ & \begin{tabular}{|l}
$\begin{array}{l}\text { Serafimovska et al. } \\
(2013)\end{array}$ \\
\end{tabular} \\
\hline Soils from an abandoned mine, Sardinia, Italy & Su Suergiu the antimony deposit & $<8-4400 \mathrm{mg} / \mathrm{kg}$ & $\begin{array}{l}\text { ICP-MS analysis after microwave digestion } \\
\text { with } \mathrm{H}_{2} \mathrm{O}_{2} / \mathrm{HF} / \mathrm{HCl} / \mathrm{HNO}_{3} /\end{array}$ & Cidu et al. (2014) \\
\hline $\begin{array}{l}\text { Soils from close to the spoil heap, Glendinning mine, SW } \\
\text { Scotland }\end{array}$ & Former Sb mine & $6.77-261 \mathrm{mg} / \mathrm{kg}$ & $\begin{array}{l}\text { ICP-OES analysis after ashing and } \mathrm{HF} / \mathrm{HNO}_{3} \\
\text { digestion }\end{array}$ & $\begin{array}{l}\text { Mcgregor et al. } \\
(2015)\end{array}$ \\
\hline Soils from a mining site, Hunan, southwest China & Banpo Sb mine & $267-5633 \mathrm{mg} / \mathrm{kg}$ & $\begin{array}{l}\text { ICP-MS analysis after acid digestion with } \\
\mathrm{HNO}_{3} / \mathrm{HF}\end{array}$ & Ning et al. (2015) \\
\hline $\begin{array}{l}\text { Soils in the vicinity of smelter, Xikuangshan Hunan, } \\
\text { southwest China }\end{array}$ & Xikuangshan mining area & $3.23-6946 \mathrm{mg} / \mathrm{kg}$ & $\mathrm{HG}-\mathrm{AFS}$ after digestion with $\mathrm{HNO}_{3} / \mathrm{HF} / \mathrm{H}_{2} \mathrm{SO}_{4}$ & Fu et al. (2016) \\
\hline Soils in and around the mining area, Glendinning, Scotland & $\begin{array}{l}\text { Mining, polymetallic mineralisation } \\
\text { including stibnite }\end{array}$ & $108-15490 \mathrm{mg} / \mathrm{kg}$ & $\begin{array}{l}\text { ICP-MS analysis after } \mathrm{HNO}_{3} \text { and } \mathrm{H}_{2} \mathrm{O}_{2} \\
\text { digestion }\end{array}$ & $\begin{array}{l}\text { Mbadugha et al. } \\
(2020)\end{array}$ \\
\hline
\end{tabular}

AFS = atomic fluorescence spectrometry, $H G=$ hydride generation, ICP = induced coupled plasma, ETAAS = Electrothermal Atomic Absorption Spectrometry, FAAS = Flame Atomic absorption spectroscopy, MS = mass spectrometry, INAA = Instrumental Neutron Activation Analysis, OES = optical emission spectrometry 